\title{
Fibrosing pneumonia - how to diagnose, and how to recognize the etiology?
}

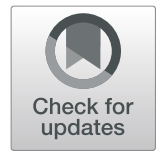

Helmut H.- Popper(D)

\begin{abstract}
Background: Fibrosing pneumonias are a group of interstitial lung diseases with a different etiologic background and divergent prognosis. They are differentiated into usual interstitial pneumonia (UIP), non-specific interstitial pneumonia (NSIP), and organizing pneumonia (OP). Some of these entities were initially described by A. Liebow.

Main: In the 90ties the main differences in survival lead to the separation of UIP/IPF as a disease with dismal outcome, from the prognostically better NSIP and OP. Later it was shown that fibrosing NSIP confers an almost identical worse prognosis. Under the heading of pulmologists a classification was created, where the diagnosis has to be established by a multidisciplinary team, based on pattern recognition done by radiologists and pathologists. A clinical diagnosis has to be established based on the patterns: UIP pattern was the basis for IPF, NSIP pattern for the clinical diagnosis NSIP, and organizing pneumonia pattern for the diagnosis of cryptogenic organizing pneumonia. This created confusion, because the pattern UIP was taken almost as synonymous with idiopathic pulmonary fibrosis (IPF). Later on in many articles and classifications the role of the pathologic diagnosis was diminished, because pulmologists based their diagnosis on CT-scan and clinical presentation. This resulted in less tissue biopsies but also delay and misinterpretation of diseases. Even new techniques in tissue biopsies such as cryobiopsy was regarded as unnecessary.

Conclusion: Tissue analysis in fibrosing pneumonias is still the gold standard in making a diagnosis and also evaluating the etiologic background. After an analysis the findings should be discussed in a multidisciplinary board to establish a final diagnosis and a treatment option for the patient.
\end{abstract}

Keywords: Interstitial lung disease, Usual interstitial pneumonia, Non-specific interstitial pneumonia, Organizing pneumonia, Autoimmune disease, Hypersensitivity pneumonia

\section{Background}

Fibrosing pneumonias have been discussed and classified several times during the last 60 years. Starting in 1969, A. Liebow created the first classification of fibrosing pneumonias, at that time under the heading of interstitial pneumonia (Liebow and Carrington 1969). At that time there was usual interstitial pneumonia (UIP), desquamative interstitial pneumonia (DIP), bronchiolitis obliterans organizing pneumonia and diffuse alveolar damage, lymphocytic interstitial pneumonia (LIP), and giant cell interstitial pneumonia (GIP). In the late 1990-ties two other proposals for classification

Correspondence: helmut.popper@medunigraz.at

Institute of Pathology, Medical University of Graz, Neue Stiftingtalstrasse 6, 8036 Graz, Austria appeared: Katzenstein (Katzenstein and Fiorelli 1994; Katzenstein 1993) and Colby (Daniil et al. 1999; Nicholson et al. 2000). Katzenstein added nonspecific interstitial pneumonia (NSIP) to the classification, and the group around T. Colby added respiratory bronchiolitis, and compared the outcome of NSIP versus UIP. In the following years the American Thoracic Society and the European Respiratory Society created consensus panels, which formulated new classifications and sorted the entities in idiopathic and Interstitial Lung Disease (ILD) with known etiology. At present the newest classification appeared in 2013 and also additional publications sorted other ILD accordingly (Travis et al. 2013; Fischer et al. 2015). There are three entities regarded as idiopathic, UIP, NSIP, and cryptogenic organizing pneumonia, which latter

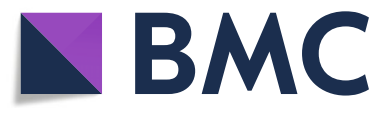

(c) The Author(s). 2020 Open Access This article is licensed under a Creative Commons Attribution 4.0 International License, which permits use, sharing, adaptation, distribution and reproduction in any medium or format, as long as you give

appropriate credit to the original author(s) and the source, provide a link to the Creative Commons licence, and indicate if changes were made. The images or other third party material in this article are included in the article's Creative Commons licence, unless indicated otherwise in a credit line to the material. If material is not included in the article's Creative Commons licence and your intended use is not permitted by statutory regulation or exceeds the permitted use, you will need to obtain permission directly from the copyright holder. To view a copy of this licence, visit http://creativecommons.org/licenses/by/4.0/. 
correspond to organizing pneumonia by morphology. Other pneumonias with a known etiology are LIP, which correspond to an immune/autoimmune disease, DIP and RB-ILD, which are both smoking associated diseases in almost all cases, GIP being either associated with hard metal disease, or viral infection. Diffuse alveolar damage (DAD) is most often associated with viral infection, or drug induced lung disease, only very rare might be idiopathic. DAD also can be seen in toxic inhalation injury, for example induced by insectizides or pestizides. When DAD is resolvedresolving, it usually will present as organizing pneumonia (also called organizing DAD).

It should be noted, that NSIP is often associated with immune diseases, either autoimmune, or hypersensitivity. However, there are still cases, for which no etiology can be assigned. In this review we will address the morphologic patterns for UIP, NSIP, and OP. In addition, we also will focus on morphologic features, which allow a more precise evaluation of the etiology of these patterns. Although the ATS/ERS recommendations now

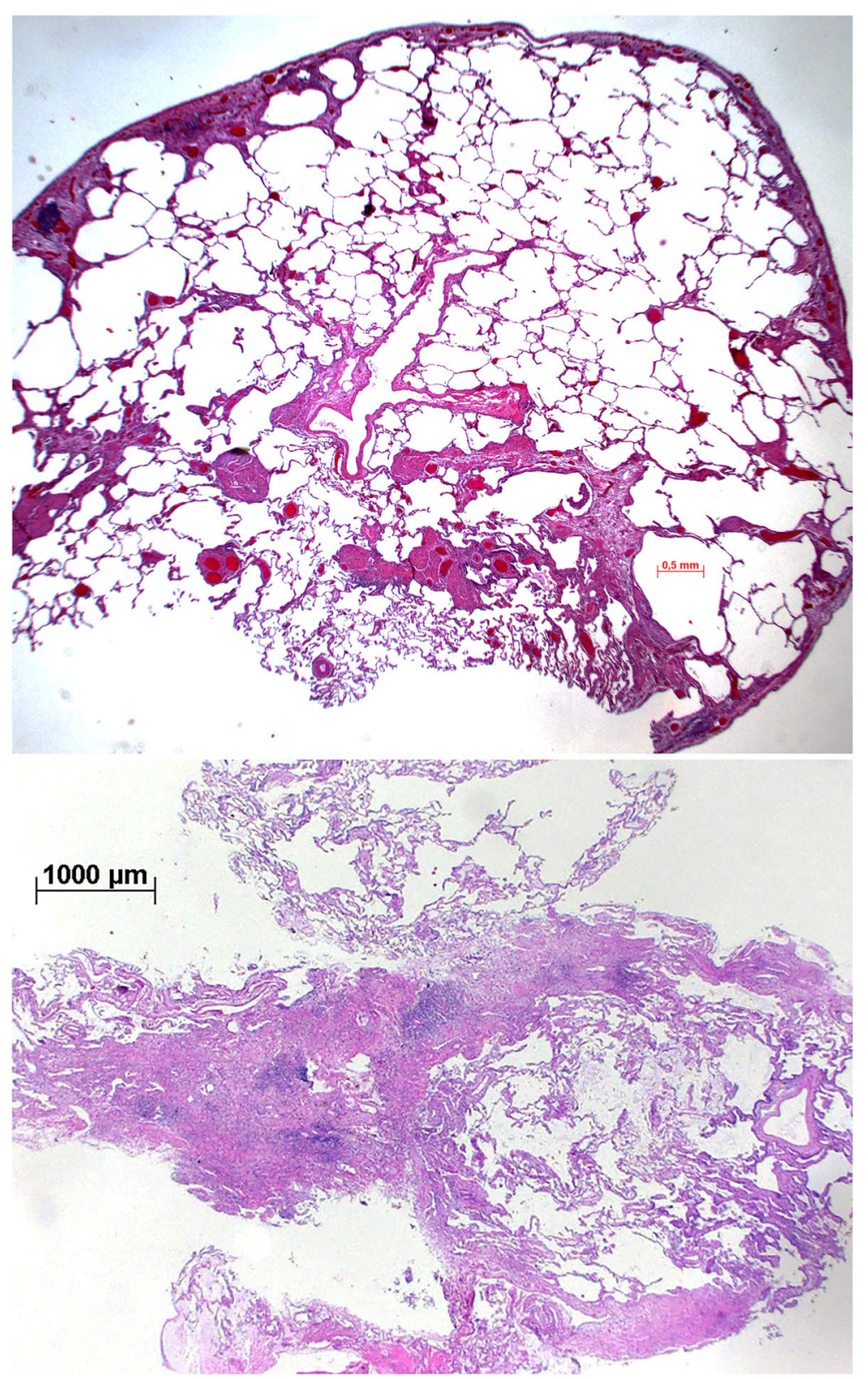

Fig. 1 Overview of UIP/IPF. The upper figure demonstrates the peripheral distribution of fibrosis. There is a lot normal lung visible. In the lower figure there is more fibrosis, also normal lung (heterogeneity), and lymphocyte aggregates around the cystic structures. H\&E, bars 500 and $1000 \mu \mathrm{m}$ 
state, that CT scan might be sufficient to make the diagnosis of IPF, NSIP, and OP, in the authors experience this holds not true: In my consultation practice I had to correct several cases, which have been labeled by the radiologist as either UIP, or NSIP, or undefined fibrosis. The statement by ATS/ERS that cryobiopsies should not be done in IPF/UIP cases can also not be confirmed, as in a cooperation with a large Pulmonology Department we have not seen complications, and the tissue was in more that $90 \%$ suitable to make a definite diagnosis and guide the clinicians. The new guidelines propose clinical findings and $\mathrm{CT}$ scans as the most important methods to diagnose UIP/IPF and reduced histopathology for those cases, where the CT scan cannot provide a definitive pattern. In addition a consensus is now the gold standard instead of histopathology. This provoked a critical review about the role of pathology in the diagnosis of fibrosing pneumonias and their etiologic background.

\section{Material and methods}

The review is based on 296 cases from middle and northern Europe including my University serving local clinical departments. All these cases represent fibrosing pneumonias of one of the above-mentioned entities. A patient consent was not necessary, as no clinical data were used, except the final diagnosis. In addition, all cases were anonymized.

Hematoxylin and Eosin stained sections were most often sufficient, a Movat pentachrome stain was applied in selected cases. This stain allows the simultaneous detection of elastic fibers, mucus, old and young fibrosis (green-turquoise for early fibrosis-immature collagen, yellow for old fibrosis-collagen 1) (Garvey et al. 1986).

Immunohistochemistry was done in some cases, using antibodies for CD3, CD4, CD8, CD20, and FOXP3, if necessary - i.e. in cases with a diffuse lymphocytic infiltration. For example in chronic hypersensitivity pneumonia there are very often areas with active disease, characterized by a predominance of $\mathrm{CD} 8^{+}$lymphocytes.

\section{UIP pattern}

In UIP some characteristic features should be present. On low power magnification the morphologic changes are peripheral accentuated often subpleural (Fig. 1). On medium power magnification a geographic distribution is typically found, i.e. there are areas of fibrosis and active disease, and areas of uninvolved, normal lung lobules (Fig. 2). On high power magnification a temporal heterogeneity is seen: there are myofibroblastic foci, old fibrosis, and remodeling of the lung with microcystic areas, or large cystic areas composed of several primary lobules (Fig. 3) - this is what the radiologist see as honeycombing. The cystic remodeled structures are due to the destruction by the myofibroblastic foci, which results in obstruction of bronchioles, destruction of alveolar septa, followed by repair. Myofibroblasts will stain positively for smooth muscle actin, but usually less intense compared to smooth muscle cells of bronchi and pulmonary blood vessels (Fig. 4). This might be sometimes used to separate myofibroblastic foci from other kind of fibrosis. In the literature the name fibroblastic focus is widely used; however, these are essential myofibroblasts,

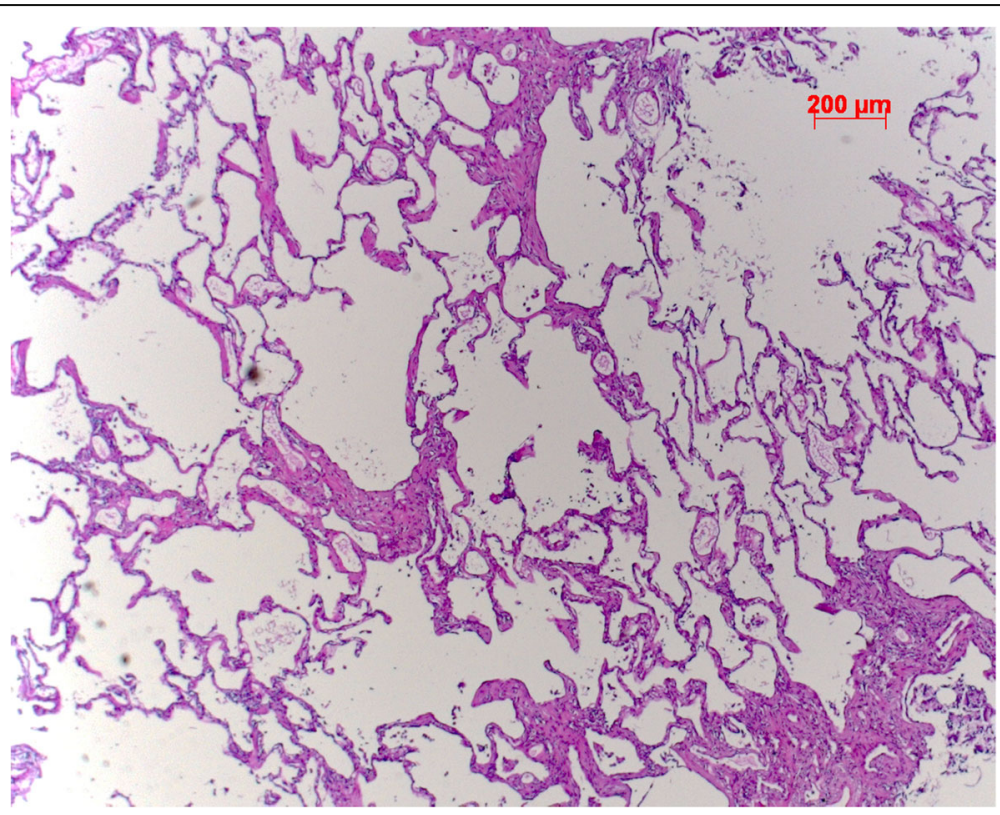

Fig. 2 In this case of UIP there are areas of fibrosis, few myofibroblastic foci, and normal lung. H\&E, bar $200 \mu m$ 

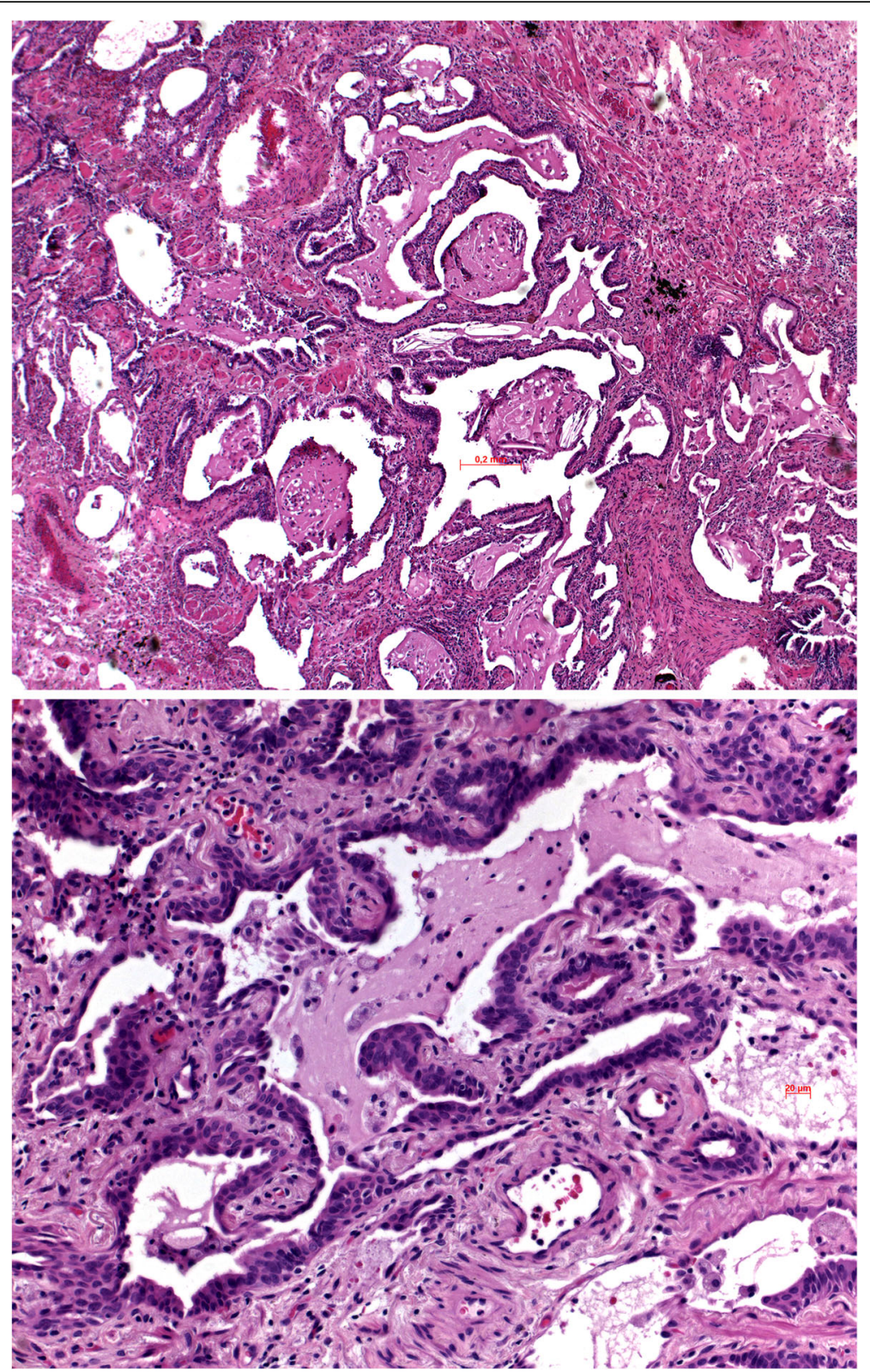

Fig. 3 Two cases of UIP with cystic remodeling, in the upper panel also fibrosis and mucus accumulation within the lumina. In the lower panel the epithelial metaplasia is illustrated with cuboidal cells of bronchiolar origin, replacing the pneumocytes. H\&E, bars 200 and $20 \mu \mathrm{m}$

which can be highlighted by a smooth muscle actin stain. The cells contain few myofilaments, and in addition can synthesize collagens.

These cystic structures are prone to mucostasis, colonization by infectious organisms, and therefore lymphocytes or granulocytes might accumulate in the wall of these cysts (Fig. 5). This most likely has nothing to do with the etiology of UIP, but rather a secondary effect. The development of lymph follicles in general and lymphocytic infiltrations into the myofibloblastic foci, however, might have some meaning with respect to the underlying etiology (see below). UIP most important is not a diagnosis (Table 1), but rather a descriptive term. It includes different etiologies, which we discuss below.

\section{What makes UIP an IPF?}

Before we can discuss this question, we need to recall, what is known about the etiology of idiopathic pulmonary fibrosis (IPF). Although the etiology is still not clear, there are at least some aspects known: IPF is a disease of the elderly, presenting most often from the 5th decade on. It is seen predominantly in smokers. The disease 

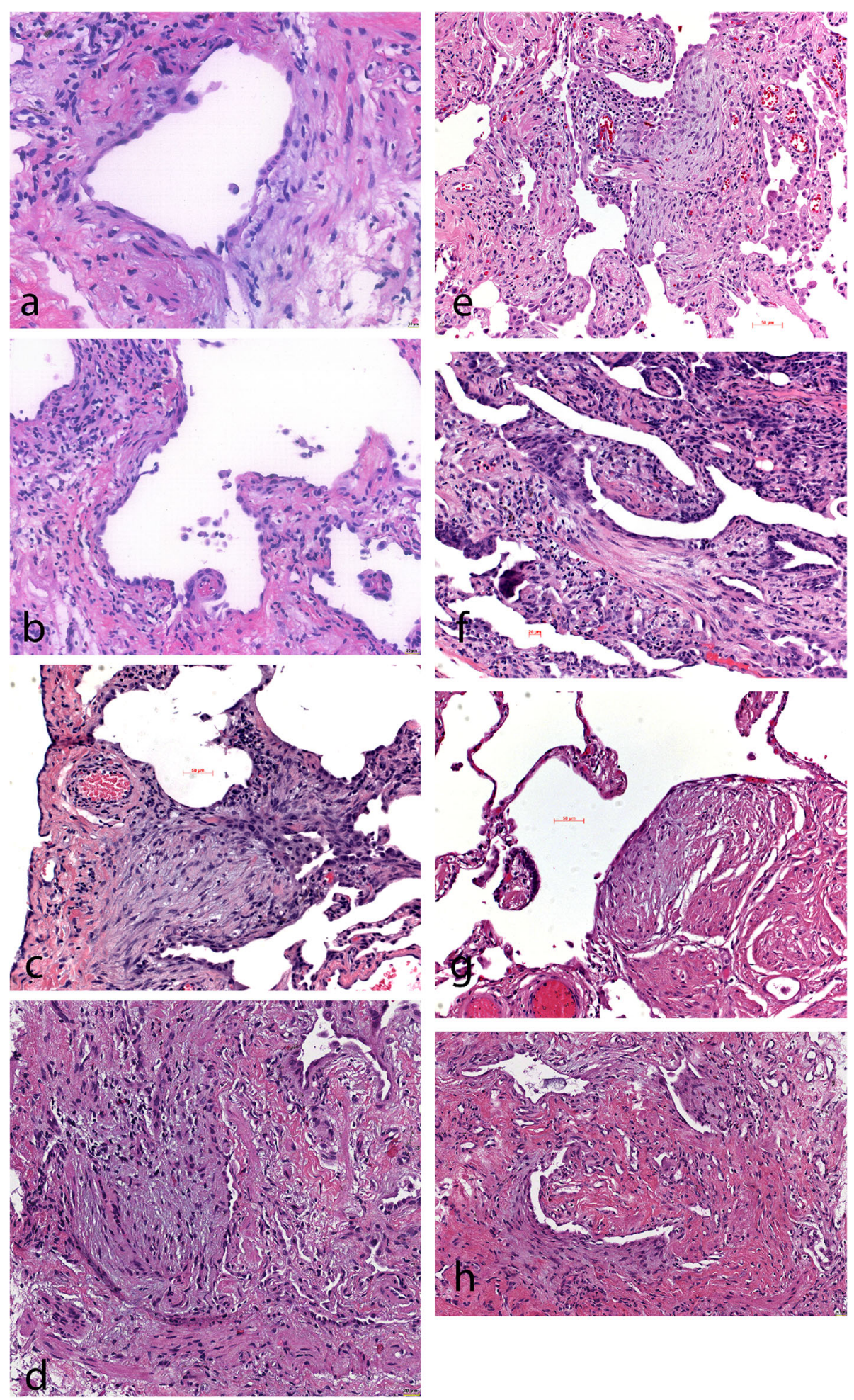

Fig. 4 Myofibroblastic foci at different age are shown; a), b), and c) young myofibroblastic foci with few cells (a and $\mathbf{b}$ ) and abundant myxoid matrix, in c) more cellular lesion but still myxoid matrix; in $\mathbf{e}$ ) and $\mathbf{f}$ ) there is focal maturation of the myofibroblasts, characterized by an eosinophilic cytoplasm and collagen fibers; in $\mathbf{h}$ ) young and old myofibroblastic foci are side by side. This nicely demonstrate the development of these lesions, where the myofibroblasts change their phenotype and slowly acquire a more fibroblastic one. H\&E, bars 50, 20, and $10 \mu \mathrm{m}$, respectively 

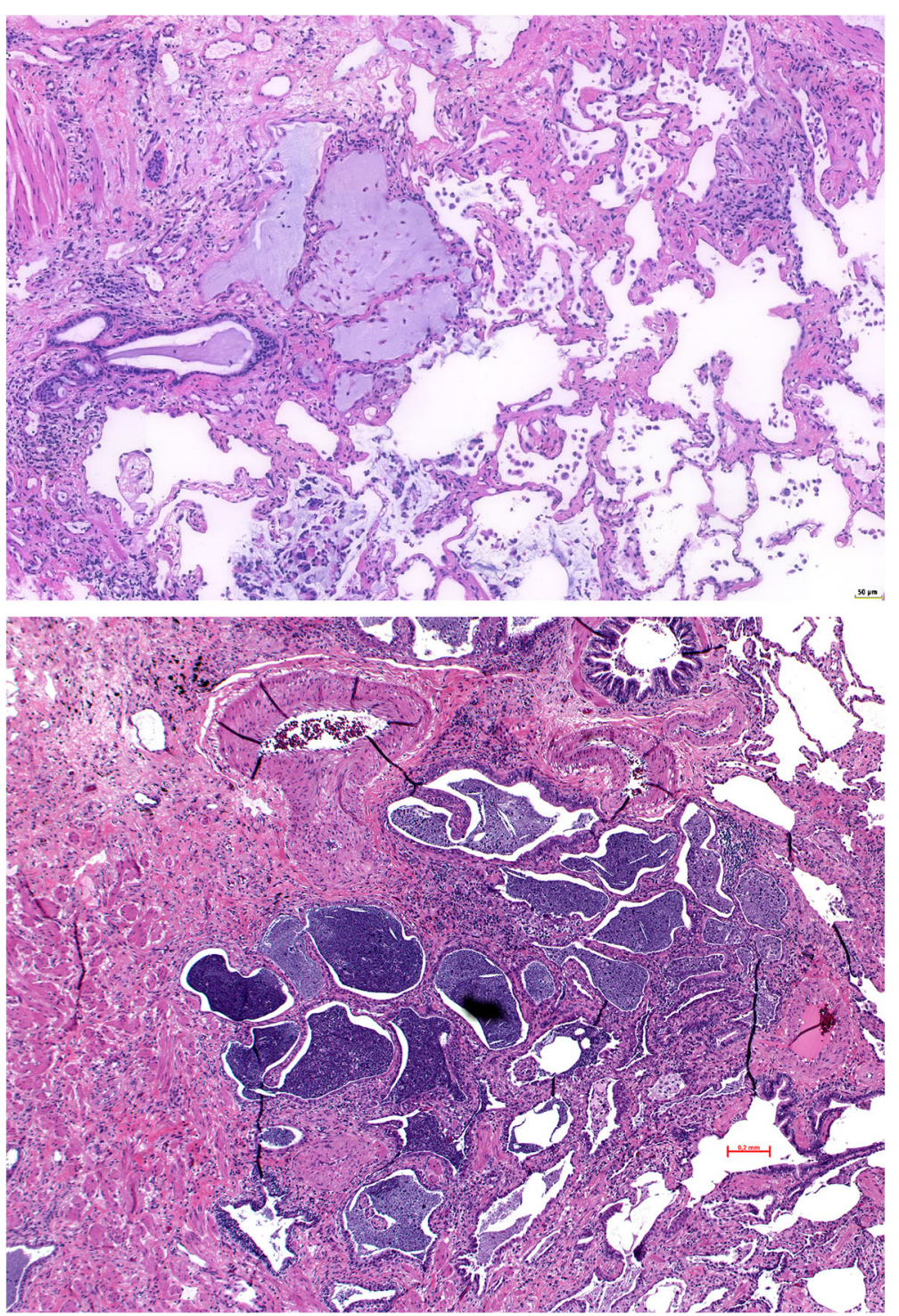

Fig. 5 Mucostasis, in the cystic structures in UIP; in the upper panel there is mucus accumulation with a few scattered macrophages; in the lower panel there is dense spissated mucus, macrophages and scattered neutrophils; this usually is a sign of bacterial colonization. There are also aggregates of lymphocytes around the cysts, which later on can progress into lymph follicles. H\&E, bars 50 and $200 \mu \mathrm{m}$

Table 1 Criteria of UIP pattern

\begin{tabular}{llll}
\hline & Definite UIP & Probable UIP, at least two features should be present & Definite not UIP \\
\hline Myofibroblastic foci scarce or abundant & yes & yes & Yes/no \\
Cystic remodeling with bronchiolar metaplasia & yes & Yes/no & no \\
Timely heterogeneity, i.e. normal alveolar septa & yes & Yes/no & No \\
Geographic heterogeneity, i.e. peripheral predominance & yes & Yes/no & No \\
Fibrosis, scar & yes & no & Yes/no \\
\hline
\end{tabular}




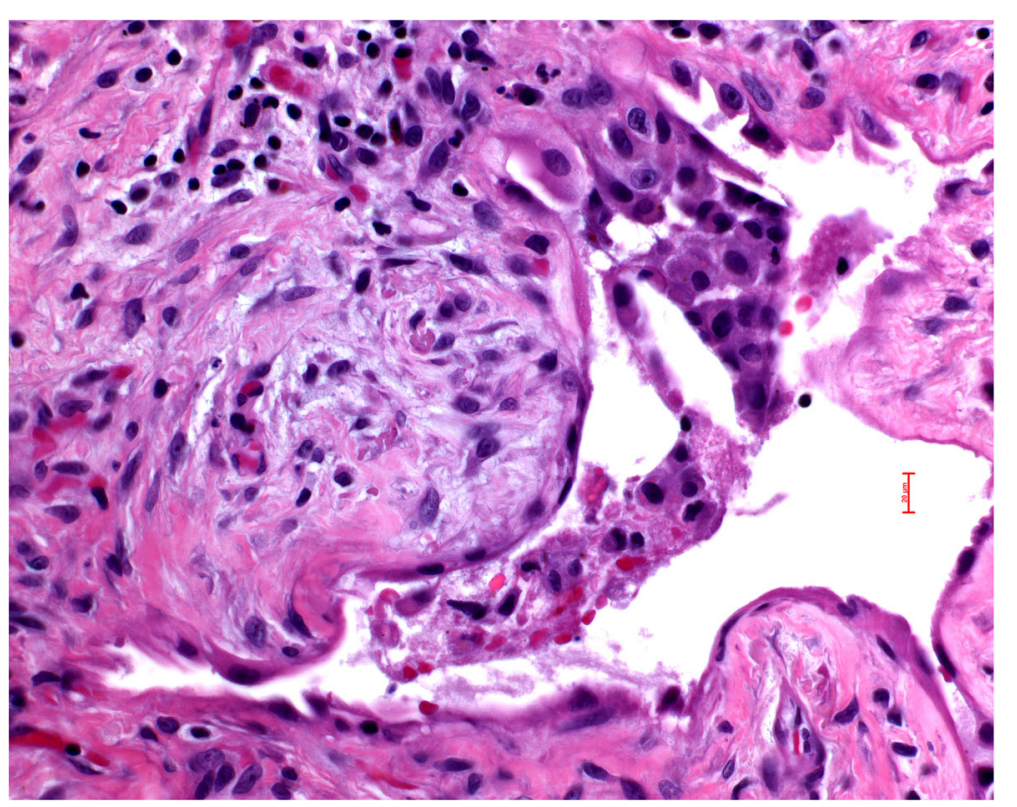

Fig. 6 Myofibroblastic focus with apoptosis of the pneumocytes; there is also a tiny focus where the surface is denuded. H\&E, bar $20 \mu \mathrm{m}$

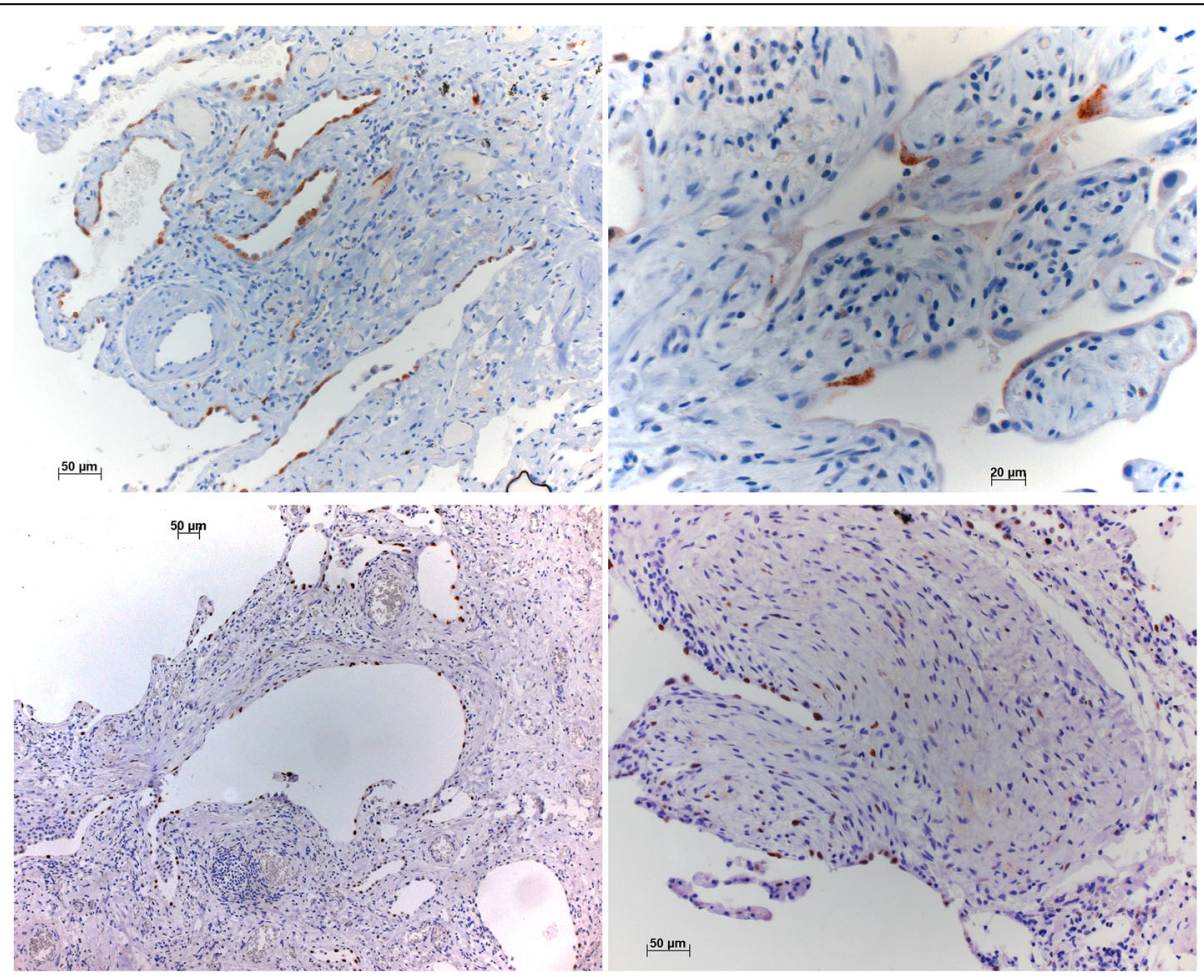

Fig. 7 Senescence in IPF, in the upper figures the senescent cells are stained by p16 (cytoplasmic), in the lower figures the cells are stained by p21 (nuclear). Both are surrogate markers for senescent cells. Bars 50 and $20 \mu \mathrm{m}$, respectively 
presents with a rapid downhill course, many patients will die within 3 years after diagnosis (Travis et al. 2013; du Bois and Wells 2001; Costabel and King 2001). Smoking induces injury in the peripheral lung, causing apoptosis of pneumocytes and bronchiolar epithelia (Fig. 6). Regeneration of these epithelia seems to be impaired, and some cells undergo senescence (Fig. 7) (Selman et al. 2010; Selman and Pardo 2014; Chilosi et al. 2013; Kuwano et al. 2016; Cardenes et al. 2018; Waters et al. 2018). Myofibroblasts start proliferating covering the denuded alveolar walls - this is a normal repair process. However, in contrast to normal, this repair does not stop (Fig. 8). The reason might be, that out of the pneumocytes senescent cells appear/transform, which induce an inflammatory environment by secreting inflammatory cytokines (Cardenes et al. 2018). These senescent cells probably very likely keep the repair ongoing. The myofibroblasts primarily produce and secrete immature matrix proteins like collagen (Katzenstein 1993), osteonectin, etc. (Fig. 9). Later on, the myofibroblasts either convert to or are replaced by fibroblasts, which produce collagen 1 and other more mature matrix proteins - fibrosis results (Fig. 4h). However, it should be mentioned, that myofibroblastic foci alone do not qualify for the diagnosis of UIP. These are repair processes, sometimes seen in smoking-related interstitial fibrosis, but in this disease associated with emphysema blebs.

Regeneration of pneumocytes is much reduced, because of aging-related dysfunction of the telomerase system, either with mutations of HTERT or telomerase (Alder et al. 2008; Cronkhite et al. 2008; Tsakiri et al. 2007). There are five different components (DKC1,
TERC, TERT, NOP10, NHP2), which encode components of the telomerase, or telomerase-associated factors, and TINF2, a telomeric protein (Kropski et al. 2014; Savage and Bertuch 2010). In the cystic remodeling areas cytokeratin 5-positive basal cells (CK5) from the small bronchi and bronchioles can be found, sometimes in early lesions completely outlining the cysts. In familial IPF other mutations have been identified, and subsequently also seen in sporadic IPF. Surfactant apoprotein $\mathrm{C}, \mathrm{A} 1$ and A2 mutations were the first being described (Markart et al. 2007; van Moorsel et al. 2010; Wang et al. 2009; Nathan et al. 2016). Mutations in these surfactant apoproteins caused stress reaction in endoplasmic reticulum, probably because of misfolded proteins (Zhong et al. 2011; Lawson et al. 2011). This might contribute or being closely associated with premature aging of pneumocytes. Other less well understood mutations or modifications are found in ABCA3 and MUC5B gene (promoter variant) (Young et al. 2008; Seibold et al. 2011). Autophagy has also been discussed as being involved downregulated in IPF (Kuwano et al. 2016; Araya et al. 2013). In contrast, we have shown, that autophagy is upregulated in IPF (Popper et al. 2019). Although, it would be expected, that autophagy is downregulated, because this would impair phagocytosis of cellular debris, which in turn would stimulate prolonged inflammation and repair, upregulation has also an important meaning: Areas of remodeling are under hypoxic stress. Autophagy will help to recycle cellular debris, use it for cell survival, and gain energy under hypoxic condition by

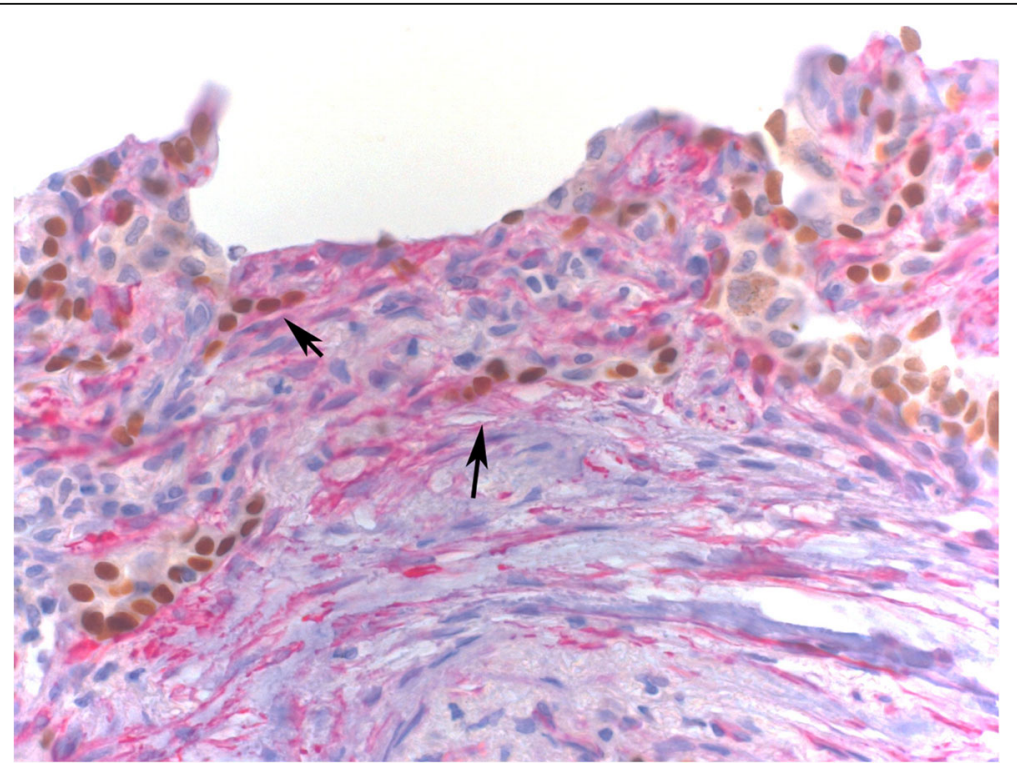

Fig. 8 UIP/IPF case, showing transition of epithelial or mesenchymal cells: TTF1 nuclear staining characterizes epithelial cells, whereas red filamentous staining for smooth muscle actin characterizes myofibroblasts. Arrows show cells coexpressing both markers. If these cells show epithelial-to-mesenchymal or mesenchymal-to-epithelial transition cannot be evaluated by morphology - both options might work. Magnification, X400 


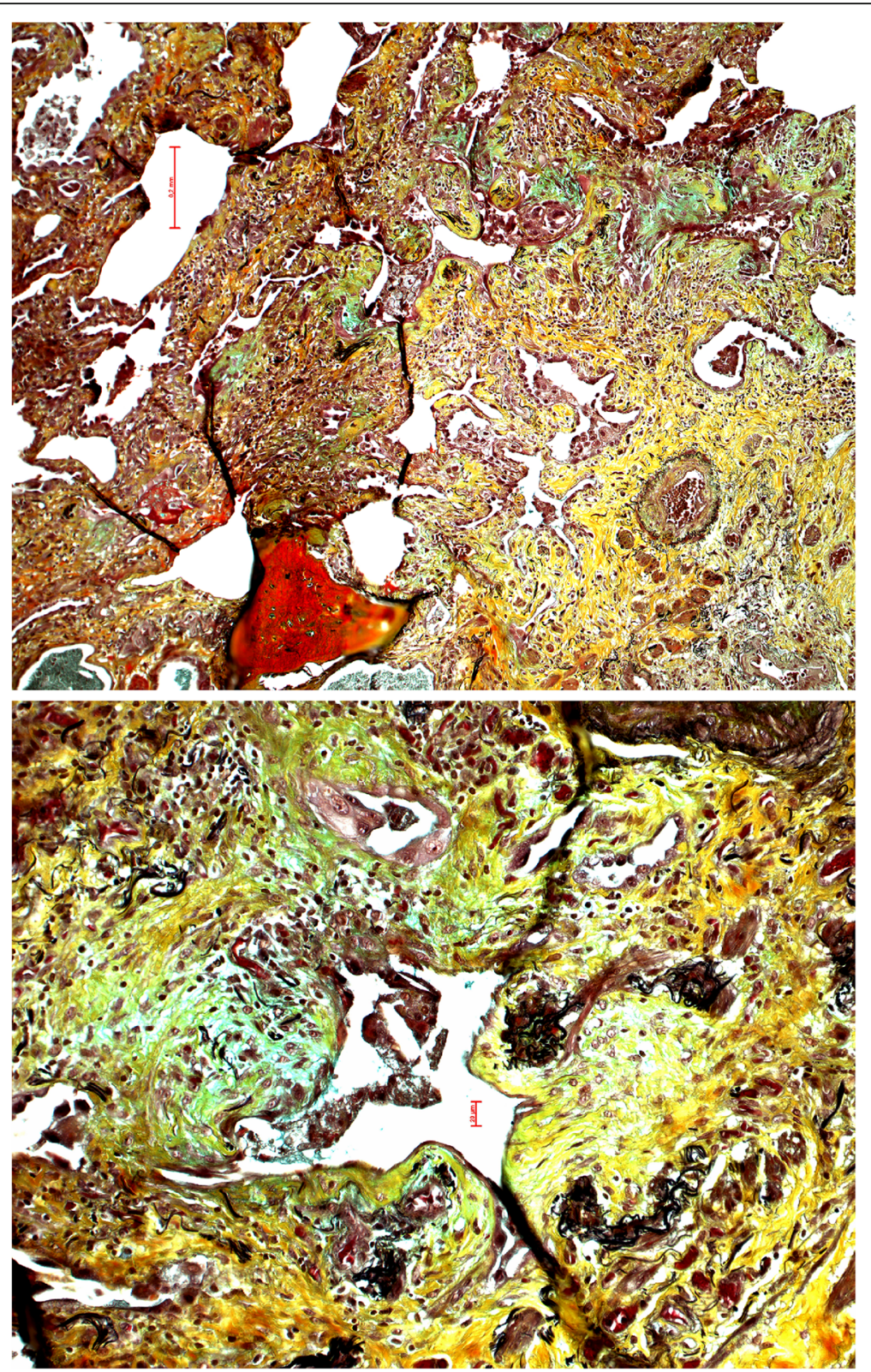

Fig. 9 Two different magnifications showing the changes of the matrix proteins in myofibroblastic foci: green for immature collagen (predominantly collagen III) and yellow mature collagen I. Movat stain, bars 200 and 20 mm

upregulation of enzymes necessary for metabolism (for example lactate dehydrogenase) (Fig. 10).

\section{What does that mean for morphology?}

Granulocytes or lymphocytes do not play a role in the early lesion, i.e. the myofibroblastic focus and the dying pneumocytes. Macrophages are sufficient to remove the debris. So, if lymphocytes are seen within young myofibroblastic foci, most likely another etiology plays a role. If in addition to all the features of UIP a diffuse lymphocytic infiltration and hyperplasia of the bronchus-associated lymphoid tissue does occur, IPF can be ruled out (Table 2) (Ozasa et al. 2018; Enomoto et al. 2014).

Here the lesion is very likely induced by an immune reaction (Figs. 11, 12 and 13). Another feature not consistent with IPF are granulomas. If these are seen in a UIP pattern, again an immune reaction has to be discussed. Granulomas, especially epitheloid cell granulomas are formed, if immune complexes cannot be 


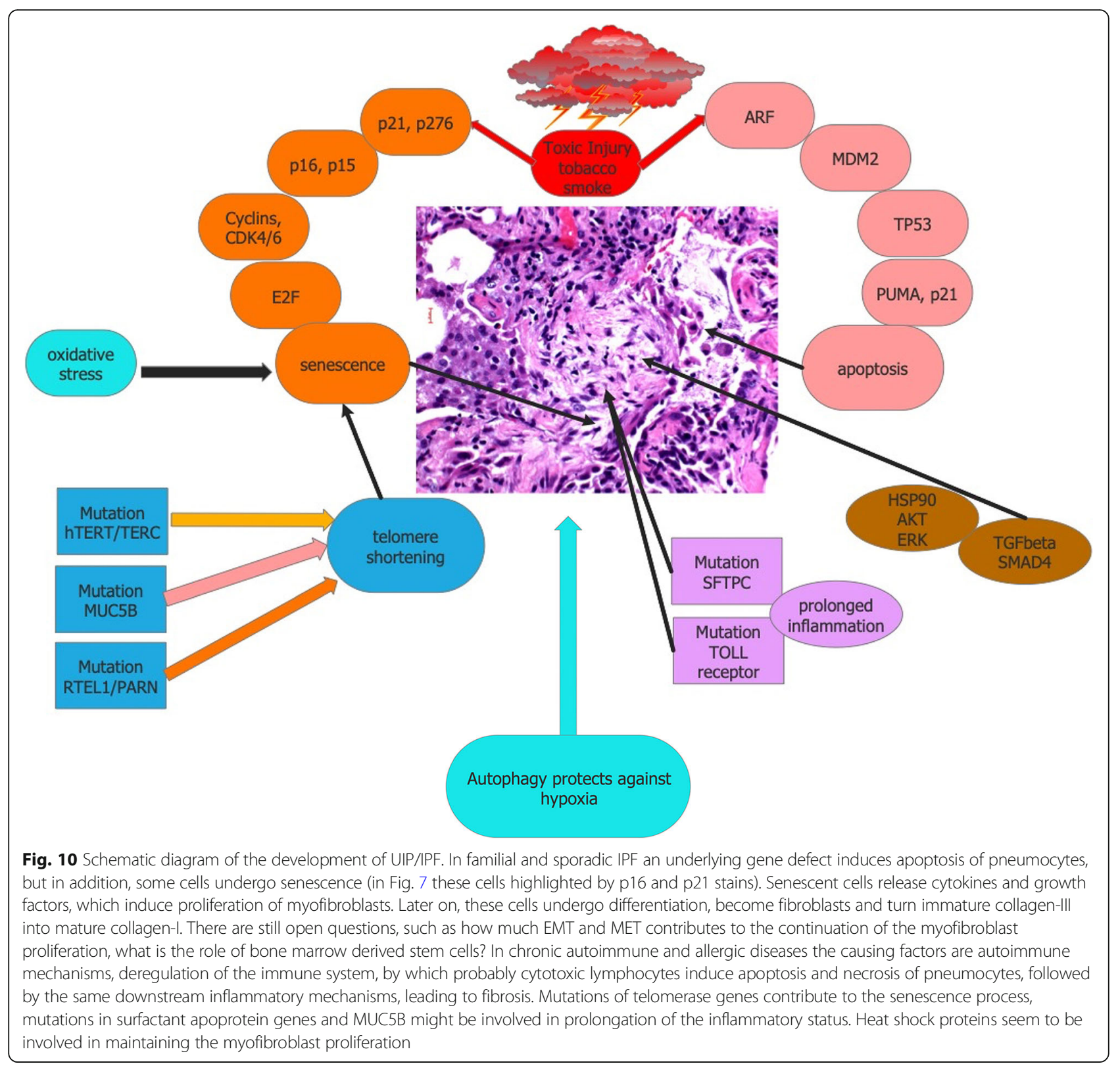

Table 2 Etiology in UIP pattern

\begin{tabular}{|c|c|c|c|c|c|c|}
\hline & $\begin{array}{l}\text { Myofibroblastic foci, cystic } \\
\text { remodeling, timely } \\
\text { heterogeneity }\end{array}$ & $\begin{array}{l}\text { LIP pattern } \pm \\
\text { hyperplasia of BALT }\end{array}$ & $\begin{array}{l}\text { Organizing } \\
\text { pneumonia } \\
\text { pattern }\end{array}$ & DAD pattern & $\begin{array}{l}\text { Granulomas } \\
\text { or giant cells }\end{array}$ & $\begin{array}{l}\text { Lymphocytes, } \\
\text { subtypes? }\end{array}$ \\
\hline $\mathrm{IPF}$ & present & no & no & $\begin{array}{l} \pm \text { in } \\
\text { exacerbation }\end{array}$ & no & No \\
\hline $\begin{array}{l}\text { Chronic } \\
\text { autoimmune } \\
\text { disease }\end{array}$ & present & Yes/no & Yes/no & no & Yes/no & $\begin{array}{l}\text { Mixed CD4/8 and } \\
\text { CD20 population }\end{array}$ \\
\hline $\begin{array}{l}\text { Chronic } \\
\text { hypersensitivity } \\
\text { pneumonia }\end{array}$ & present & $\begin{array}{l}\text { Yes/no peribronchial } \\
\text { lymphocyte aggregates }\end{array}$ & yes & no & yes & $\begin{array}{l}\text { Predominant CD8 } \\
\text { population }\end{array}$ \\
\hline
\end{tabular}




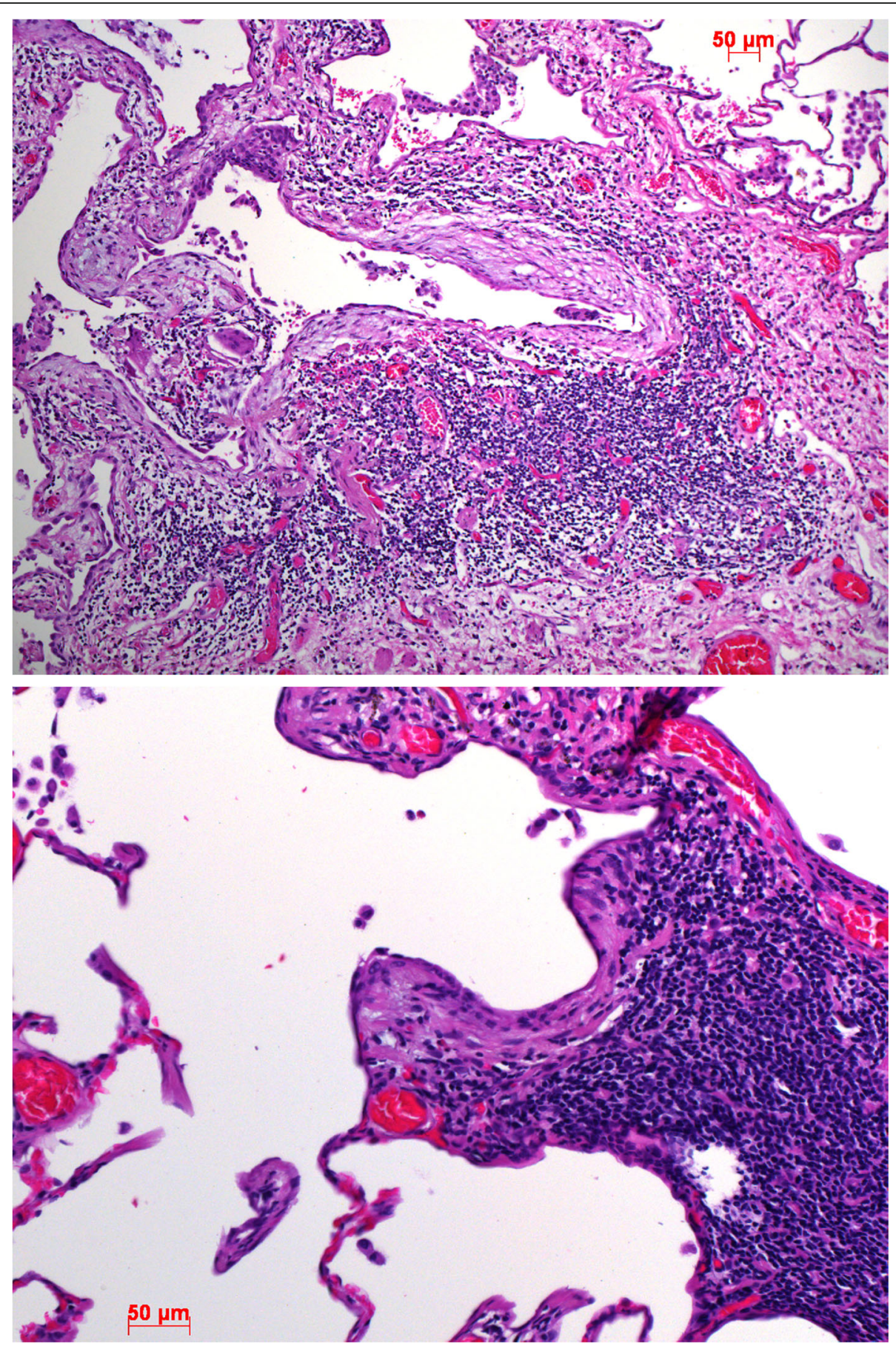

Fig. 11 Myofibroblastic foci in two cases of immune induced UIP/chronic autoimmune disease. Note the infiltration of lymphocytes in these young myofibroblastic foci. H\&E, bars $50 \mu \mathrm{m}$

removed/dissolved by leukocytes (Fig. 14). Therefore, macrophages undergo a differentiation into epitheloid cells, and others into giant cells, which start to degrade the immune complex. If the immune complex is part of an autoimmune disease or a hypersensitivity reaction cannot be solved on morphology. However, there are some diseases, which regularly present with granulomas, such as hypersensitivity pneumonia (HP), rheumatoid arthritis (rhA), and dermatomyositis (DMM). Others such as systemic lupus erythematosus (SLE), systemic 


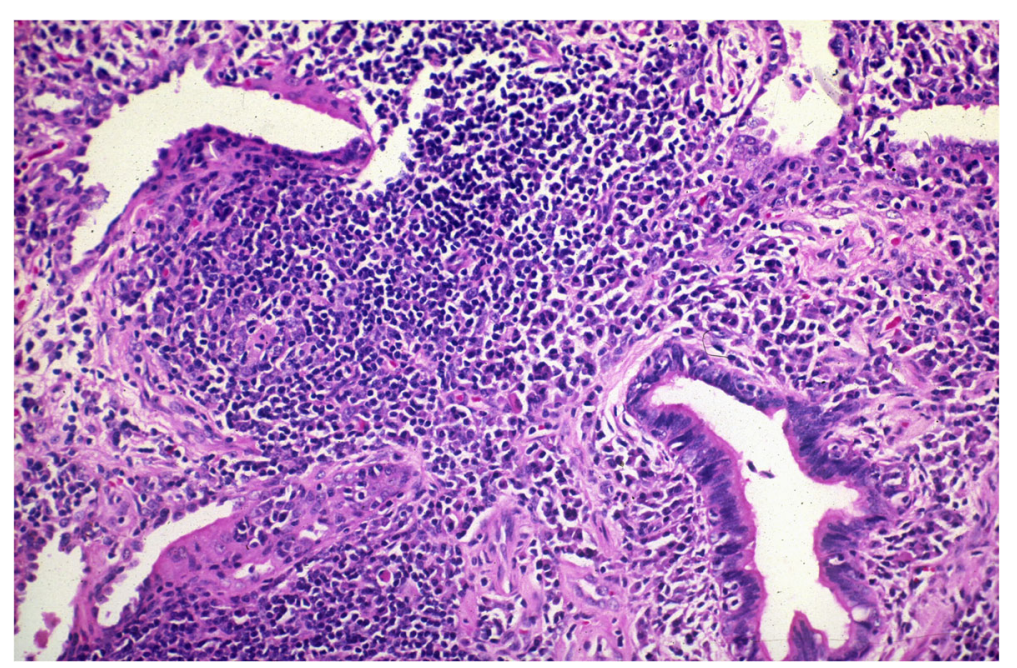

Fig. 12 Hyperplasia of the bronchus-associated lymphoid tissue (BALT hyperplasia), another sign of autoimmune diseases. H\&E, X200

sclerosis (SSc), and polyserositis rarely will induce granuloma formation - most likely because they do create huge idiotypic-antiidiotypic immune complexes. In addition, SLE in my personal experience will rarely present with an UIP pattern.

If UIP pattern is present in an autoimmune disease, it is a sign of chronicity. In these cases, it might clinically be difficult to identify the underlying autoimmune disease. This might be a reason, why the ATS/ERS classification labelled this as IPAF. However, in my opinion in many cases a careful analysis of the tissue might provide additional features, which could help the clinician to assign a final etiologic diagnosis to the patient. Immune complex deposition, amyloid deposits, infarcts, hemorrhage, granulomas, hyperplasia of BALT system, LIP, these all will help to sort the spectrum of autoimmune diseases according to a probability schema Table 3.

In the ATS/ERS classification there are additional comments for uncertainties in the diagnosis of UIP. The recommendations therefore have added terms such as definite UIP, indeterminate UIP, probably UIP, alternate diagnosis (Raghu et al. 2018). This reflects in my opinion the fact, that biopsies are rarely done; this is also expressed in this statement: "for patients with newly detected ILD who have a high-resolution computed tomography scan pattern of UIP, strong recommendations were made against performing surgical lung biopsy, transbronchial lung biopsy, and lung cryobiopsy, and a conditional recommendation was made against performing BAL".

In histopathological evaluations the diagnosis of indeterminate UIP is rarely made, but a probably UIP diagnosis is sometimes necessary in cryobiopsy cases: for example myofibroblastic foci and cystic remodeling are present, but no normal lung parenchyma, and no fibrosis/scar. Here a pragmatic handling is recommended: If CT scan and clinical data are all in favor of UIP/IPF, no further biopsy is necessary. If the clinical history and the CT scan are not clear, an open lung biopsy might be necessary. An alternate pathological diagnosis does occur even in cases where the clinical and radiological diagnosis favor UIP/IPF. What is more common, is a question mark on the etiology: in some cases an UIP pattern is seen, but no additional features, which could direct one into either IPF or other UIP associated diseases. Again, if lymphocytic infiltrations are seen within myofibroblastic foci, this points to an immunological etiology, because lymphocytes are not involved in the initial injury in IPF.

\section{NSIP pattern}

In contrast to UIP, NSIP is uniform, there is no temporal heterogeneity. The peripheral lung structure is retained, which might be sometimes not easy to prove. There is some help: use a digitized slide and outline the alveolar septa with a pencil. By this action you will see, that the alveoli are still there, and no cysts have been formed.

NSIP comes in two versions, cellular and fibrotic. In cellular NSIP the alveolar septa are diffusely infiltrated by a mixture of lymphocytes, plasma cells, and histiocytes. In fibrotic NSIP the septa will show mild to moderate fibrosis and less inflammatory infiltrates (Fig. 20). After the initial description of 

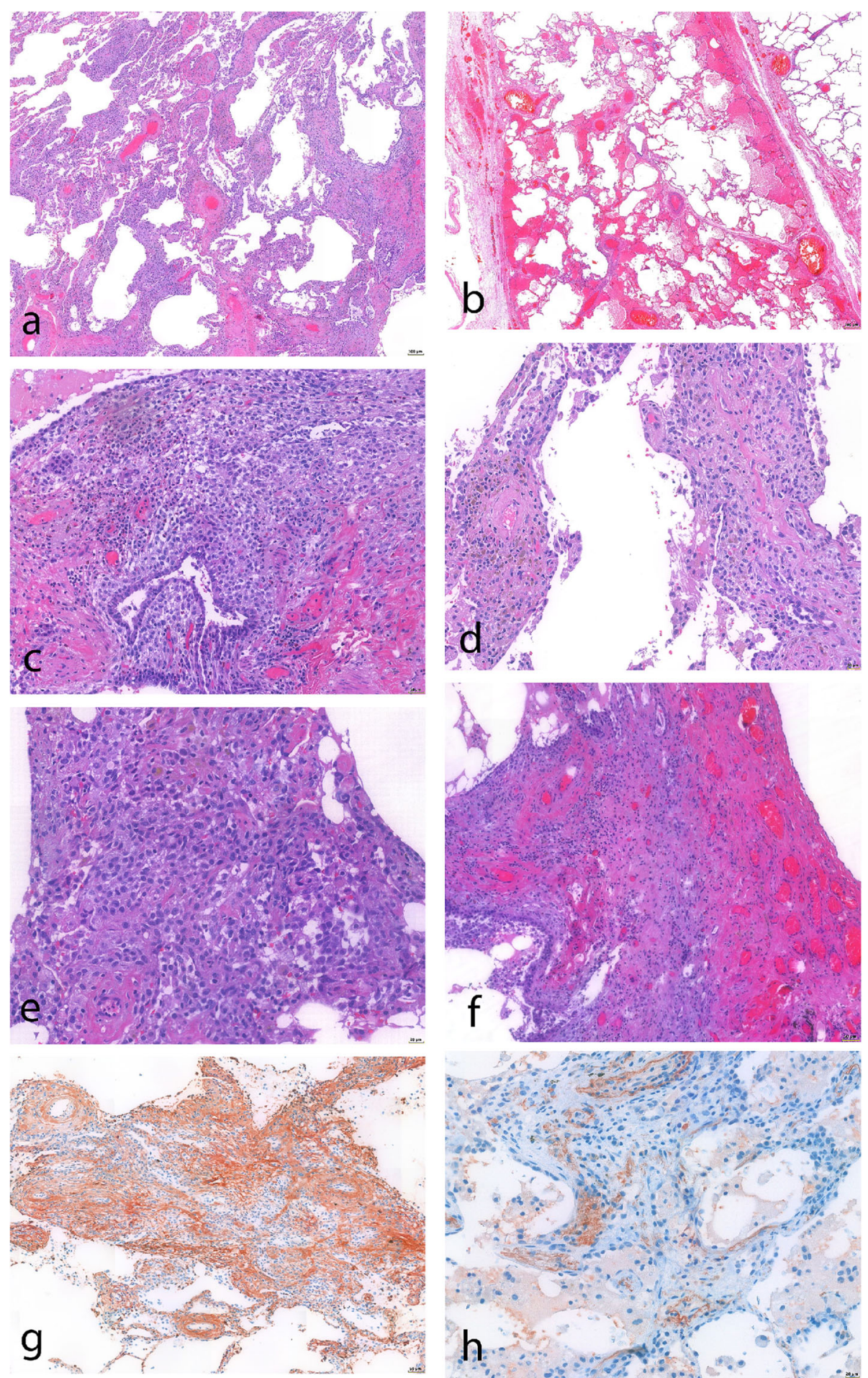

Fig. 13 Case of an autoimmune disease, probably SLE; $\mathbf{a}$ and $\mathbf{b}$ shows two different areas, one with LIP, the other with alveolar hemorrhage; in ce) there is a pattern which looks like LIP, but it could also be called NSIP; but as there is also BALT hyperplasia, which is uncommon in NSIP; in e and $\mathbf{f}$ ) there is fresh hemorrhage but also are siderin-laden macrophages; $\mathbf{g}$ and $\mathbf{h}$ ) shows deposition of immune complexes ( $\mathbf{g}$ ) and activation of the full complement cascade (h; C5-9 complex). H\&E and immunohistochemistry for IGG and C5-9, bars 200, 100, 50, $20 \mu \mathrm{m}$, respectively 


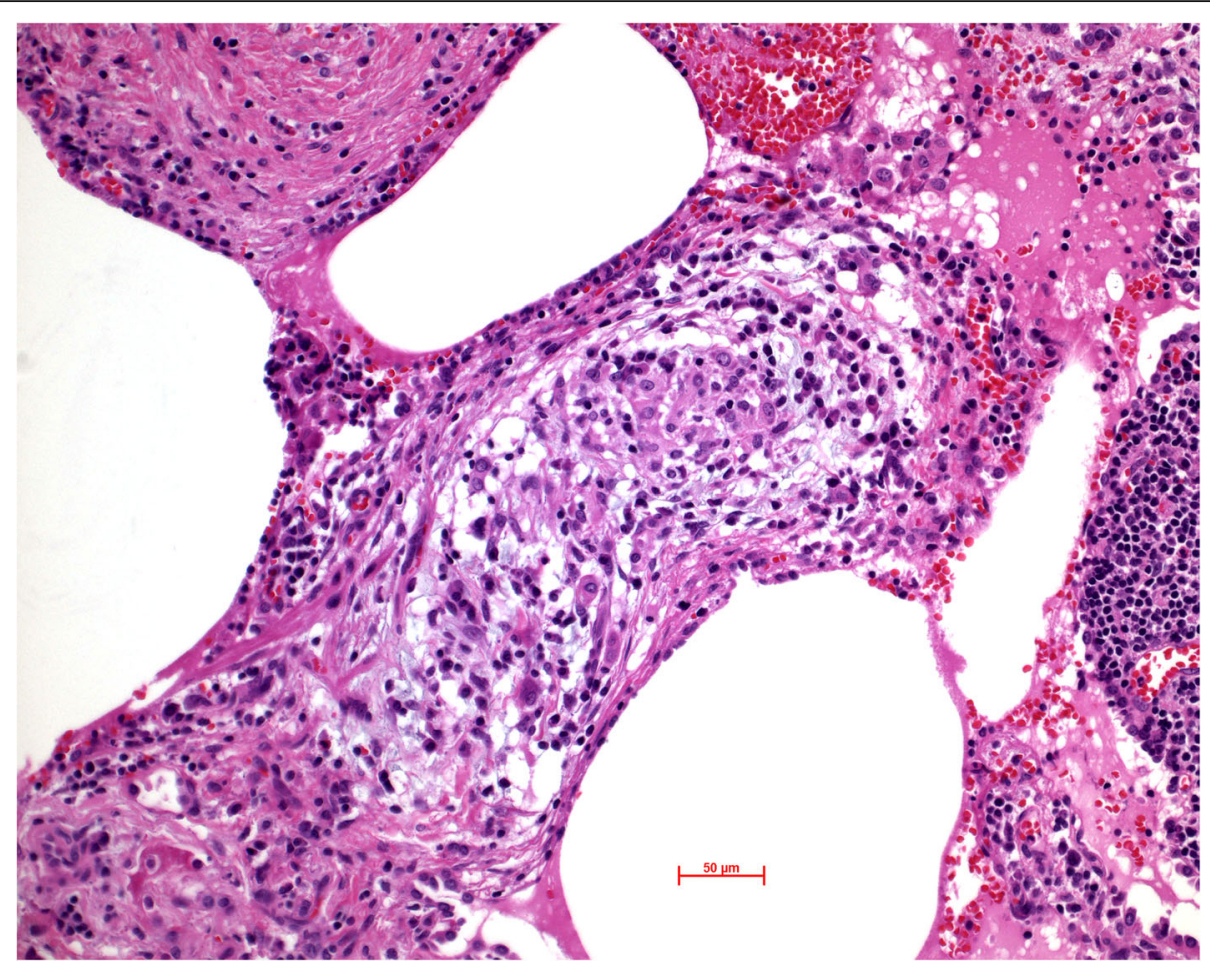

Fig. 14 Chronic rheumatoid arthritis, here with an epitheloid cell granuloma; the main differential diagnosis in such a case would by hypersensitivity pneumonia; stains for CD markers on lymphocytes will help in such a differential diagnosis. H\&E, bar $50 \mu \mathrm{m}$

NSIP (Katzenstein and Fiorelli 1994), one could see a vanishing of LIP from the literature - everything was now published under the name NSIP. However, LIP was still there.

What differs NSIP from LIP? This was also never clearly differentiated.

In NSIP the infiltrate is mixed, composed of lymphocytes, plasma cells, histiocytes, and dendritic cells, whereas in LIP the infiltrate is much more uniform, composed of lymphocytes and plasma cells (Fig. 21). In addition, in LIP there is also a hyperplasia of BALT not present in NSIP. The prognosis of cellular

Table 3 Features Combined features of some chronic autoimmune diseases

RhA: UIP pattern, LIP pattern, histiocytic or epitheloid cell granulomas, hyperplasia of BALT, amyloid deposition, mixed lymphocytes positive for CD4, CD8, and CD20. This will also help to exclude HP, which will present with predominant CD8+ cells. Rare or absent FOXP3 regulatory Tcells (Figs. 15 and 16).

SSc: UIP pattern, LIP pattern, no granulomas, hyperplasia of BALT, amyloid or immune complex deposition (Fig. 17)

SLE: hemorrhage, infarcts, immune complex deposits, NSIP or LIP pattern, OP (Fig. 18)

DMM: UIP pattern, NSIP pattern, granulomas (Fig. 19)
NSIP is usually good, whereas the prognosis of fibrotic NSIP is almost as worse as UIP (Kambouchner et al. 2014; Myers 2007).

The etiology of NSIP: There are different causes, autoimmune diseases, hypersensitivity and toxic reactions, and finally an idiopathic form (Cottin et al. 1998; Fujita et al. 2001; Kim et al. 2002; Bouros et al. 2002; Nicholson et al. 2002; Cottin et al. 2003; Arakawa et al. 2003; Tansey et al. 2004; Ohtani et al. 2005; Lee et al. 2005; Yoshinouchi et al. 2005). Some autoimmune diseases such as dermatomyositis, are preferentially seen with NSIP pattern, whereas others as rheumatoid arthritis are often associated with UIP. Toxic reactions are seen in several drug reactions, but also toxic dust inhalation.

\section{Organizing pneumonia}

Organizing pneumonia (OP) was previously called bronchiolitis obliterans - organizing pneumonia, BOOP. Due to the fact, that bronchiolitis obliterans is rarely seen on transbronchial biopsy, the name was shortened to OP. Morphologically it is characterized by granulation tissue arising from the wall of bronchioles and alveolar walls. In contrast to the proliferation of myofibroblasts in UIP, there are newly formed 
blood vessels in the granulation tissue. These granulation polyps also called Masson bodies protrude into the alveolar lumen. Usually there are mixed infiltrates visible, composed of macrophages, residual leukocytes or lymphocytes (Fig. 22). Sometimes the differentiation between myofibroblastic foci and granulation polyps can be difficult. In these cases, the other criteria for UIP should be looked up: cystic remodeling, fibrosis and scar, normal primary and secondary lung lobules. This will assist to sort the correct diagnosis.

\section{Causes of OP}

There exists a huge number of possible causes of OP. Cases of infectious pneumonias, if not solved can progress into OP. Other causes are inhalation of toxic material (including pesticides and herbicides), drug toxicity, aspiration, and distal to bronchial obstruction. OP can also present as a subacute reaction following autoimmune diseases (Fig. 23), eosinophilic lung disease, primary vasculitis, and some rare conditions such as lung involvement in chronic
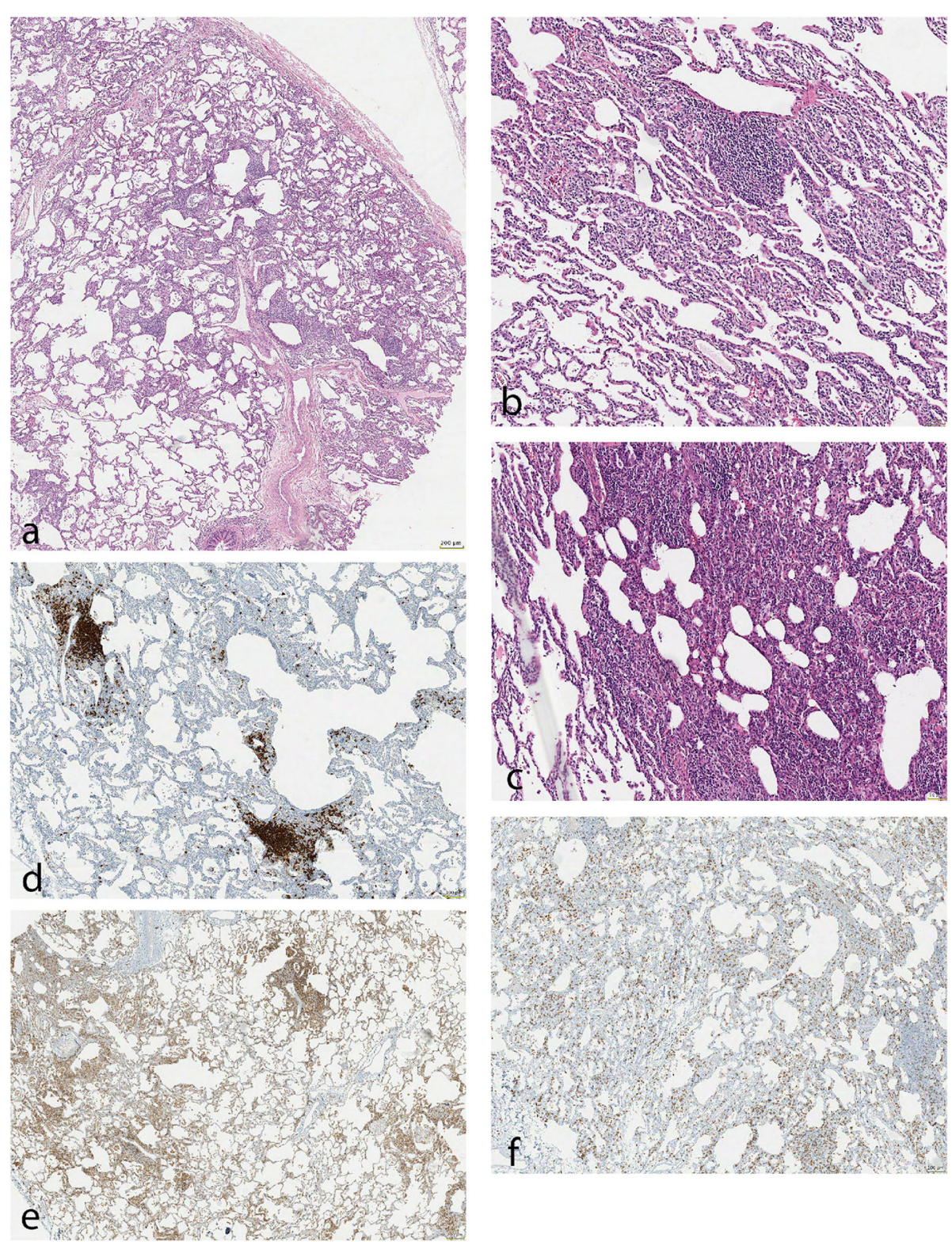

Fig. 15 rhA, acute form with LIP pattern; in this case the diagnosis of juvenile rhA was established. a) overview, $\mathbf{b}$ and $\mathbf{c}$ ) LIP with hyperplasia of BALT; d) CD20 positive lymphocytes, e) lymphocytes positive for CD4, and f) CD8 positive lymphocytes. This immune reaction excluded hypersensitivity pneumonia. H\&E and immunohistochemistry, bars 200, 100, and $50 \mu \mathrm{m}$, respectively 

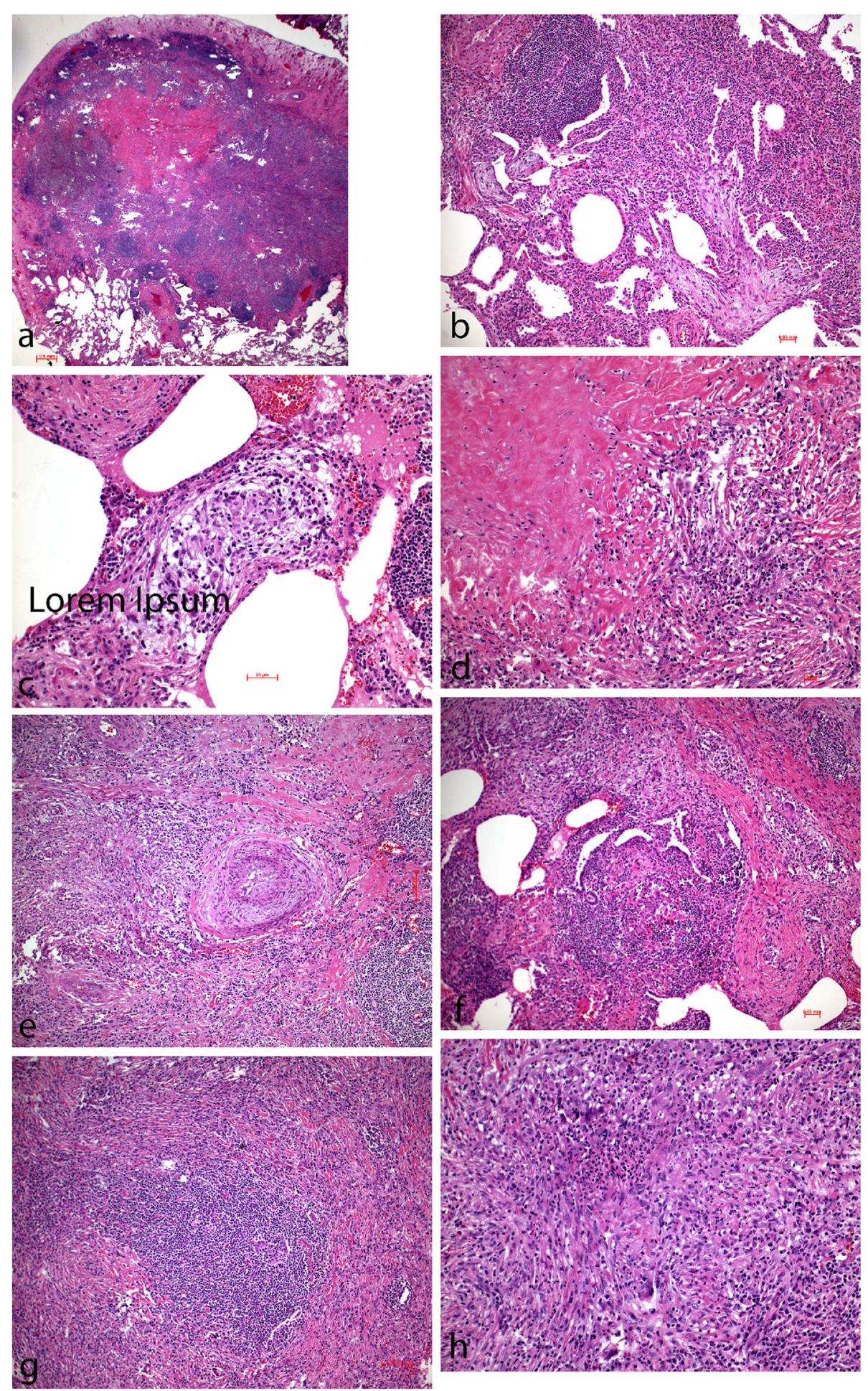

Fig. 16 Chronic rhA, a) overview, b) myofibroblastic foci with dense lymphocytic infiltration and lymph follicle, and cystic remodeling; c) lose epitheloid cell granuloma, d) amyloid deposit, e) dense lymphocytic infiltration and vasculopathy with severe narrowing of a pulmonary artery, $\mathbf{f}$ ) cystic remodeling, lose granulomas with giant cells, lymphocytic accumulation, $\mathbf{g}$ ) BALT hyperplasia, $\mathbf{h}$ ) lose granulomas and focal necrobiosis with neutrophils. H\&E, bars 500, 100, 50, and $20 \mu \mathrm{m}$, respectively 


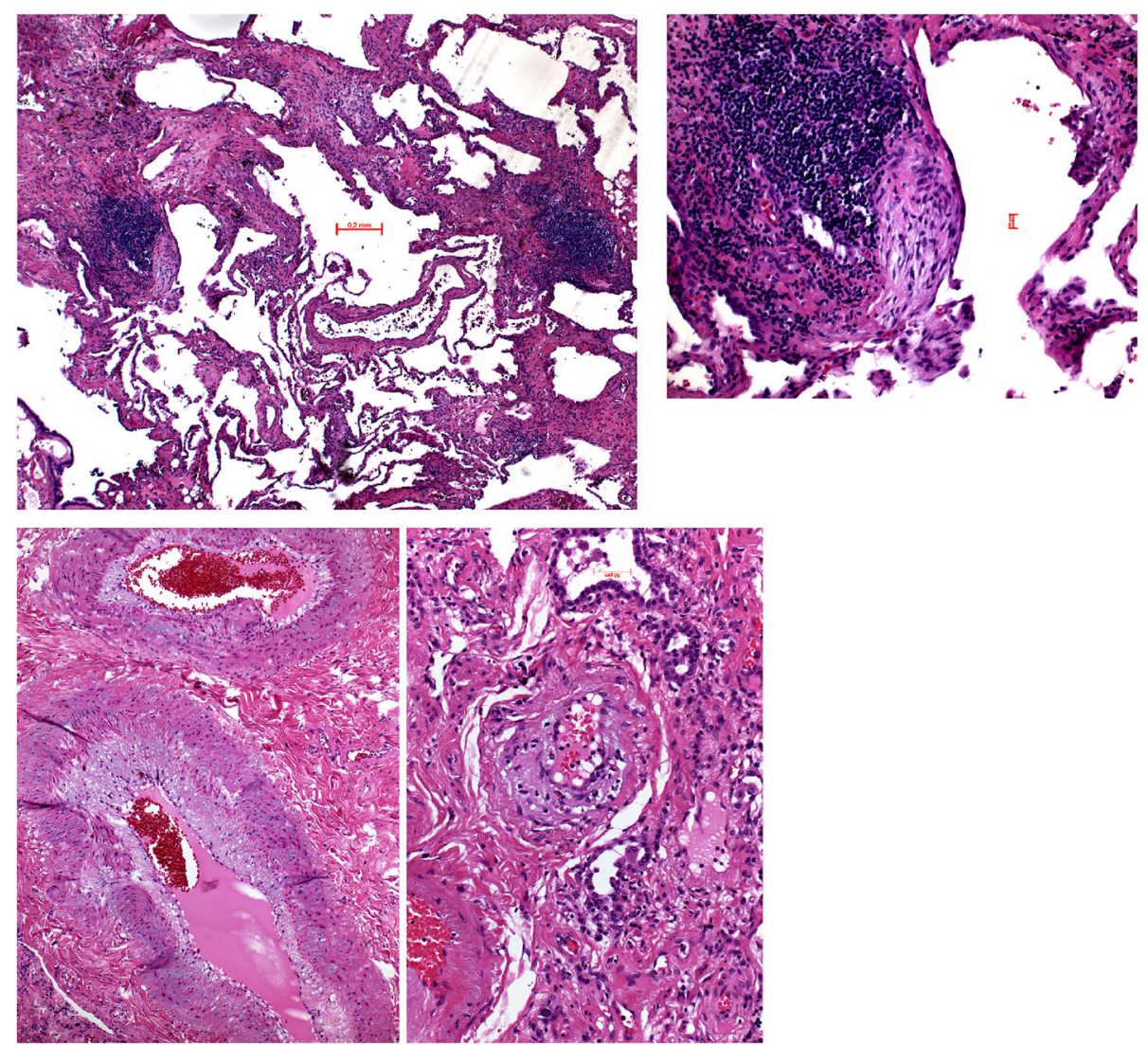

Fig. 17 Chronic systemic sclerosis (SSc); UIP pattern with myofibroblastic focus, fibrosis, cystic remodeling, but also hyperplasia of BALT. Note the dense lymphocytic infiltration into the myofibroblastic focus (top); at the bottom vasculopathy is seen with myxoid changes of the intima and narrowing of the arterial lumen. H\&E, bars 200, 50, and $20 \mu \mathrm{m}$

inflammatory bowel disease. If all these differential diagnoses have been excluded, idiopathic OP, called cryptogenic OP remains.

\section{Autoimmune diseases}

Finally, we will shortly comment on immune diseases, autoimmune as well as hypersensitivity diseases. Acute immune diseases will most often present as LIP (Fig. 15), however, subacute and chronic diseases can present either as OP, NSIP, or UIP. Prognostically there is not much difference if UIP is caused in the setting of IPF, or in the setting of autoimmune disease (Rampp et al. 2019). However, in NSIP the etiology seems to influence the prognosis: an underlying autoimmune disease has a better prognosis compared to idiopathic NSIP (Nunes et al. 2015).

How certain a diagnosis of chronic autoimmune disease can be made by morphology?

If a chronic autoimmune disease present with UIP pattern, there are usually several other features simultaneously present: granulomas, amyloid deposit, immune complex deposit, alveolar hemorrhage, infarct, vasculitis/ vasculopathy.

\section{Hypersensitivity pneumonia (HP)}

Similar to autoimmune diseases also HP can present as subacute or chronic disease. Clinically the diagnosis might be complicated, because the classic symptoms might no longer prevail. But morphology in many cases can pave the way to the diagnosis. In subacute disease HP will present with OP, but focally florid lesions often can be seen. Even in chronic HP (with UIP pattern) focally areas of active disease are seen (Fig. 24): there will be areas of BALT hyperplasia, LIP, granulomas or simply giant cells. In contrast to autoimmune disease pleuritis is absent.

\section{Conclusions}

Pathologists can arrive not only at a descriptive diagnosis, i.e. pattern description, but in some instances can direct clinicians to the etiology. 

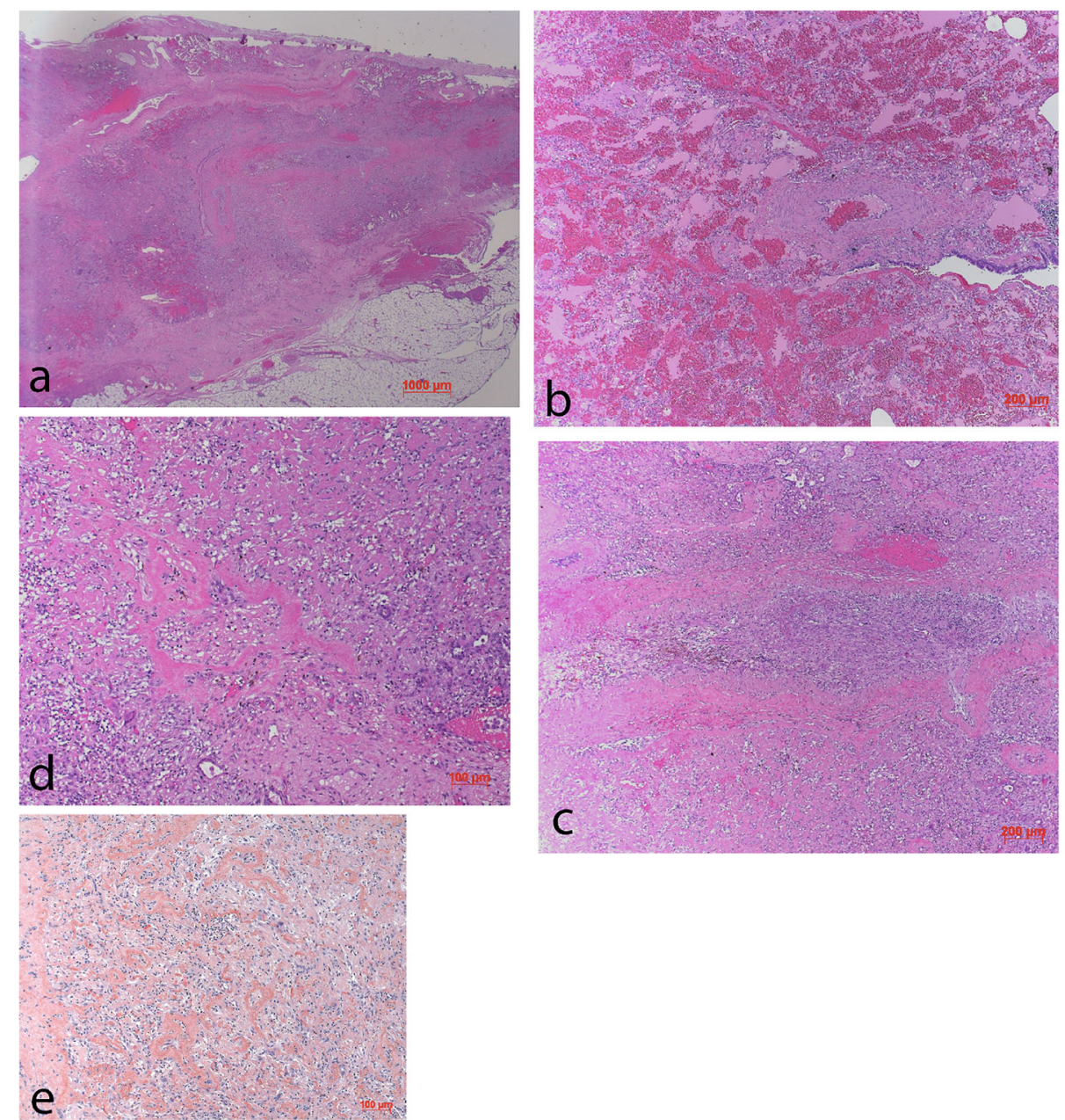

Fig. 18 SLE, a) overview, b) alveolar hemorrhage and vasculitis with thrombosis (c) and infarct; d) shows eosinophilic deposits simulating amyloid, but this corresponded to immune complexes (e). H\&E and immunohistochemistry for IGG, bars 1000, 200, and 100 um, respectively

\section{Comments of multidisciplinary boards}

In the recent consensus classification of ILD the ERS, ATS, JPS stated, that in most instances' histopathology is no longer required, only in unusual CT scan presentations a biopsy might be necessary. Cryobiopsy and BAL is not recommended. The diagnosis should be made by a board. There is a nice report on the results of such recommendations. During a meeting of pulmonologists, radiologists and pathologists each group had to analyze cases of proven IPF. When pulmonologists analyzed the cases there was a low kvalue amongst them (0.11-0.56). The same applied to the radiologists. There was also a major discrepancy between clinicians in academic centers and community hospitals. When both groups merged, there was still no good correlation. When the pathologic diagnosis was disclosed, the k-value reached 0.92 (Flaherty et al. 2007). What does that mean, if pathology is no longer the gold standard (Raghu et al. 2018)? In my personnel experience, there is a minority of IPF cases, which are correctly diagnosed by clinical and radiological data alone. Honeycombing is a feature, which is not seen in early UIP/IPF, whereas cystic remodeling in primary lung lobules can be seen in by histopathology. Myofibroblastic foci cannot be seen on CT scan. Fibrosis is not always a sign of IPF - many other diseases will cause fibrosis. Having the ability to see many consultation cases, there is a lot more to dig out of the morphology, than just UIP. This all escapes, if no more tissues are taken. On the other hand, pathologists have not done a good job by just handing over a description (UIP), instead of raising the question of the underlying etiology. So we have to learn and improve too!

Let me end with an important statement from Martin Tobin, former Editor-in-chief of the American Journal of Respiratory and Critical Care Medicine: "Controversy is 

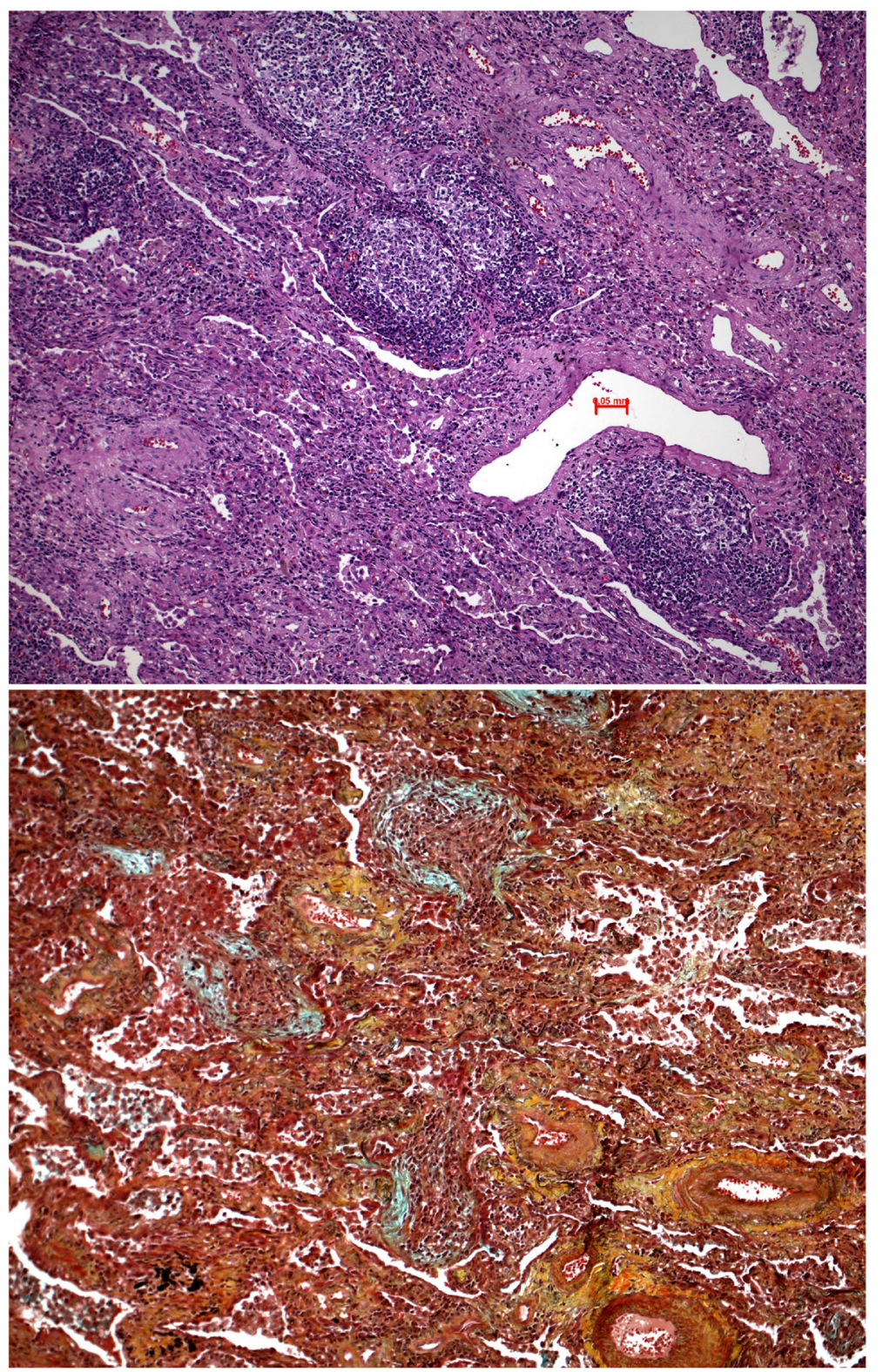

Fig. 19 Dermatomyositis, in this case the UIP pattern with myofibroblastic foci is not easily detected (upper panel), but these are highlighted by Movat stain (lower panel); there is fibrosis, cystic remodeling, but also BALT hyperplasia and sclerosis of pulmonary arteries. H\&E and Movat stain, bars $50 \mu \mathrm{m}$ 


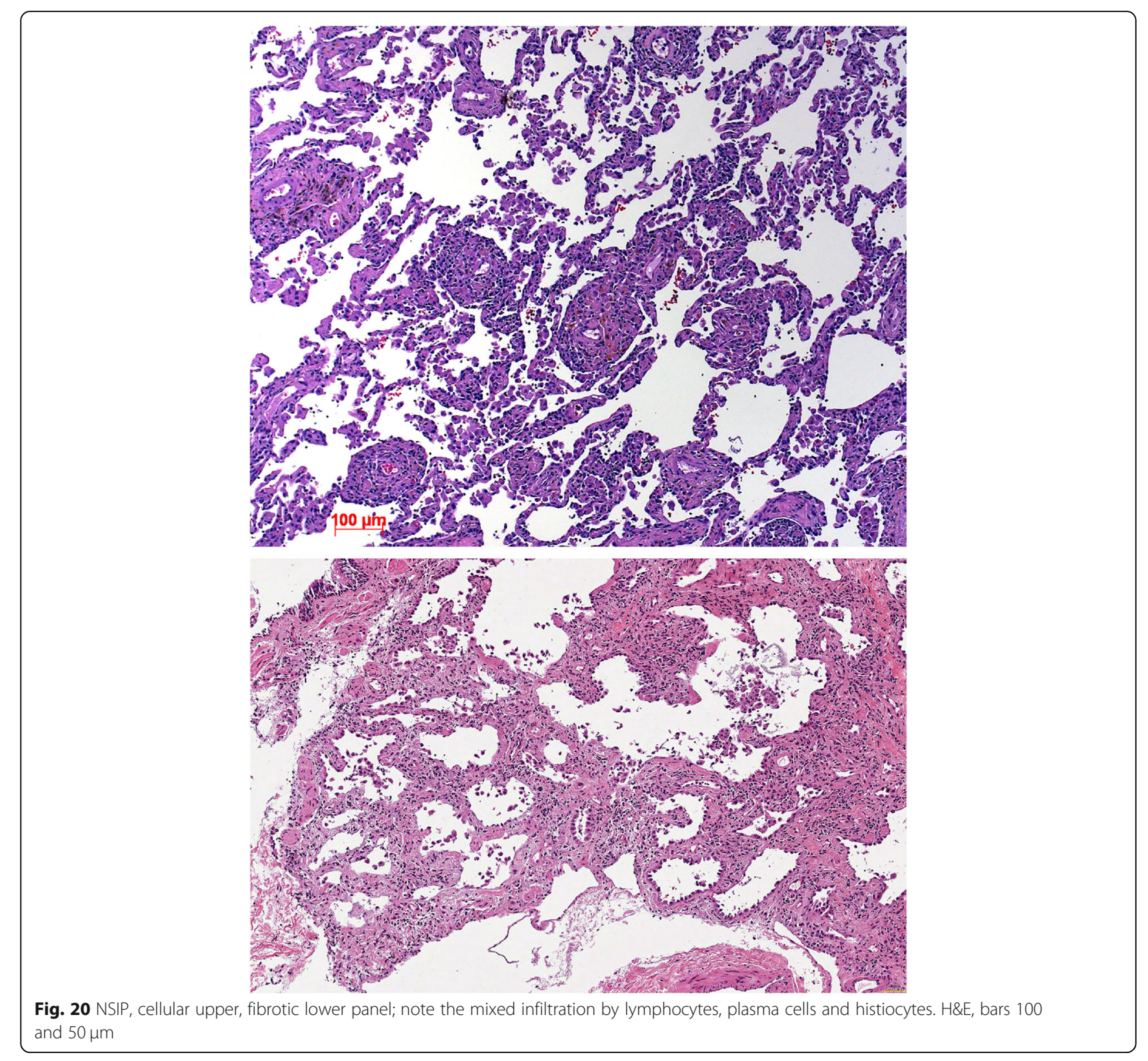




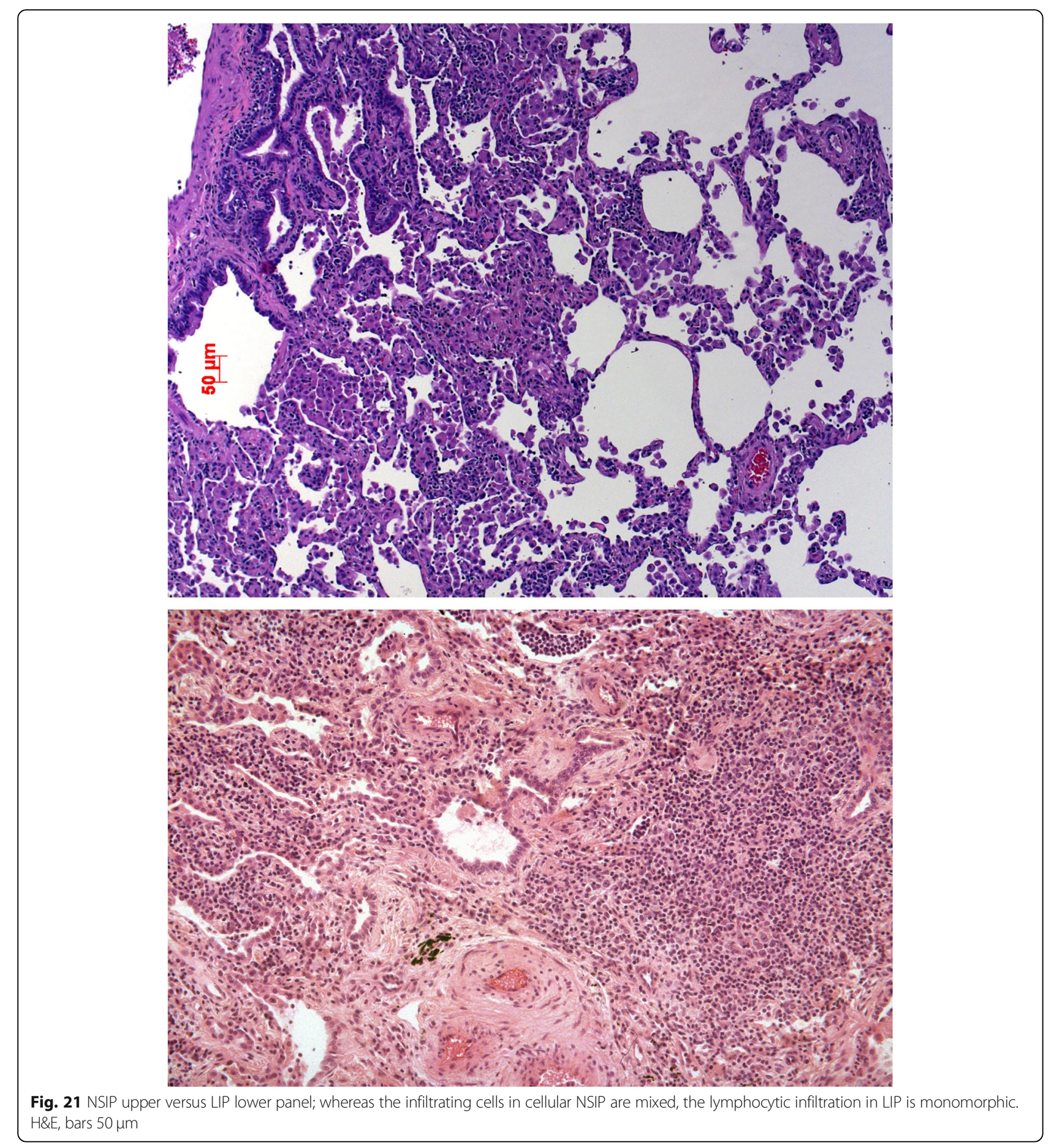




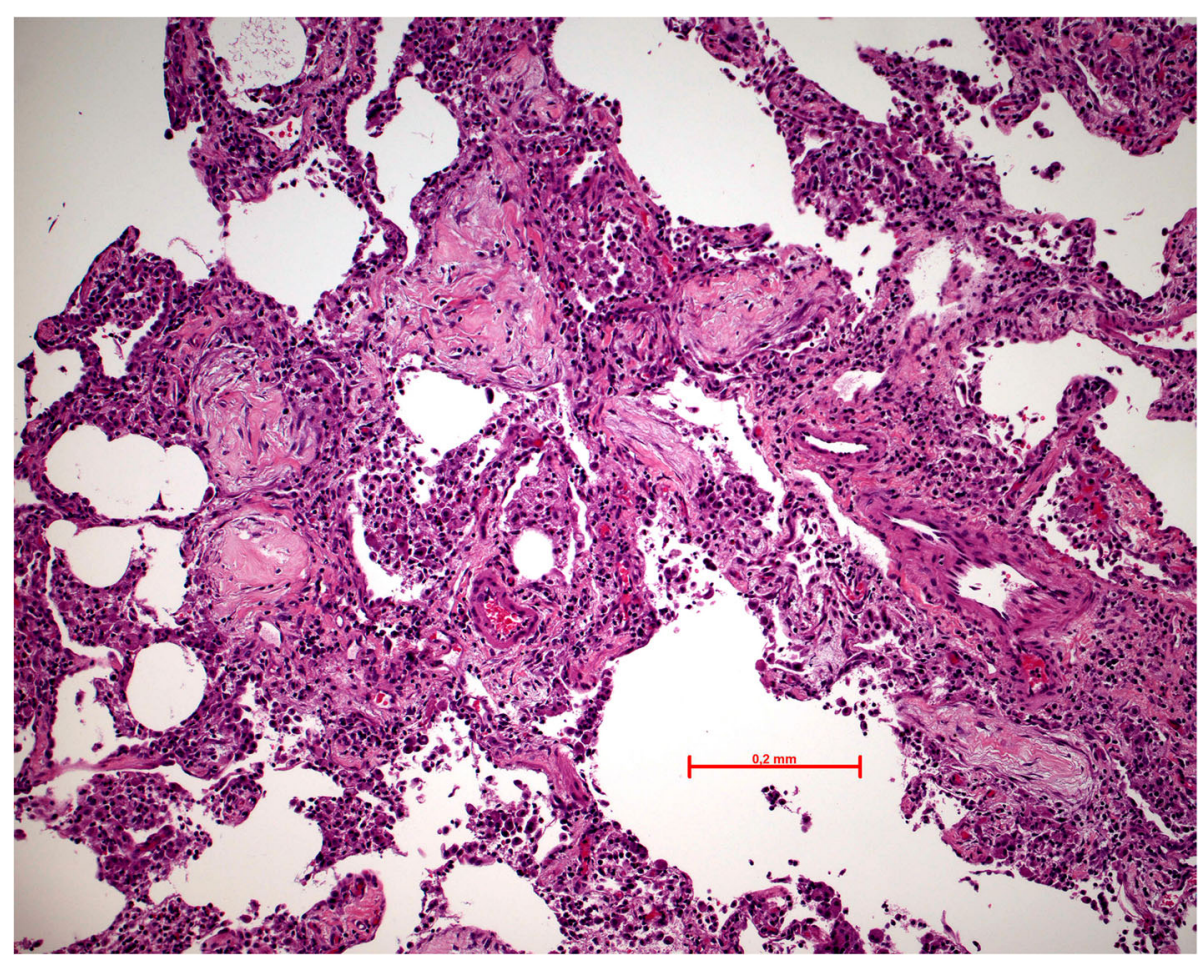

Fig. 22 Organizing pneumonia with many granulation polyps; note the newly formed blood vessels within these polyps. H\&E, bar $200 \mu \mathrm{m}$

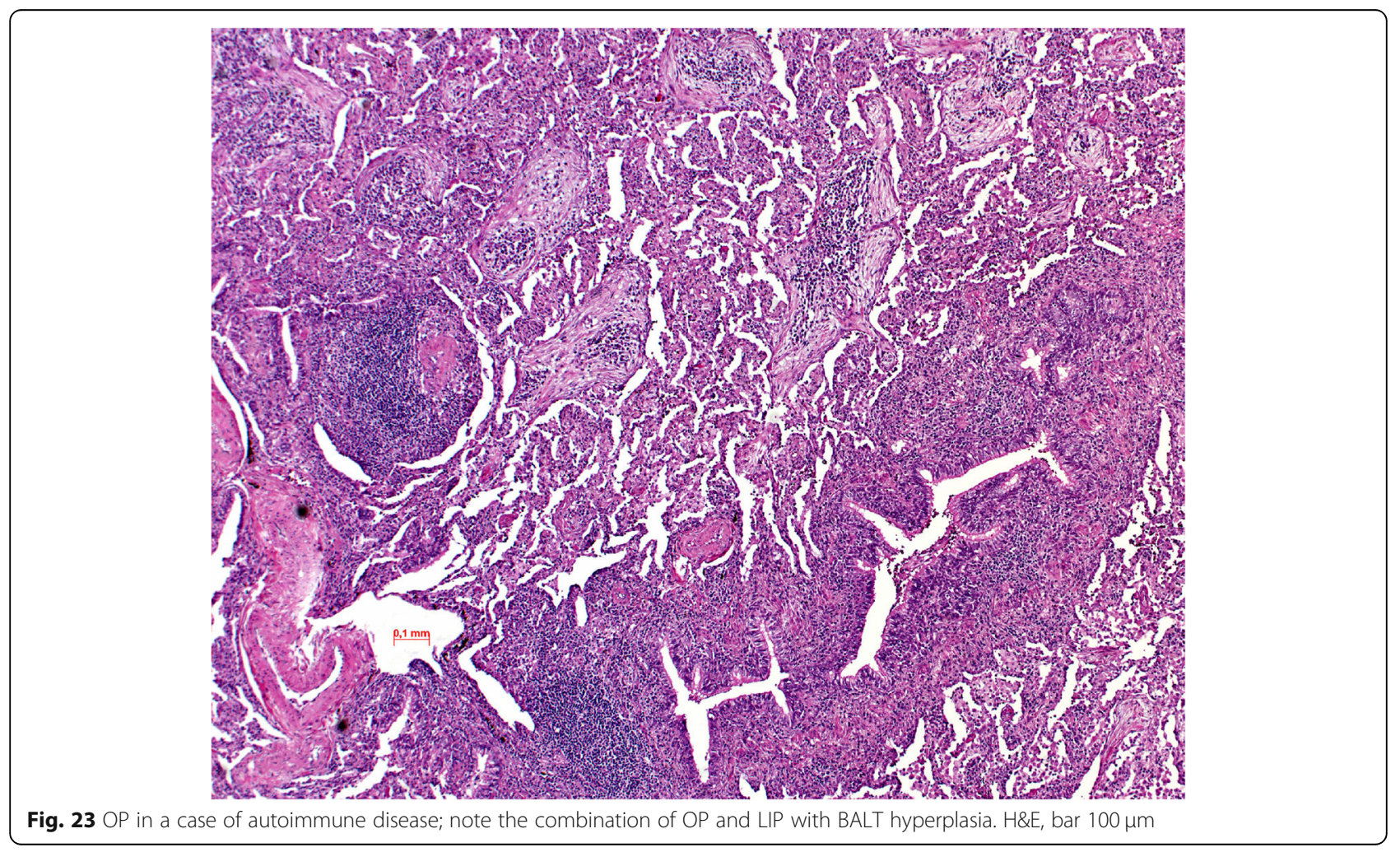



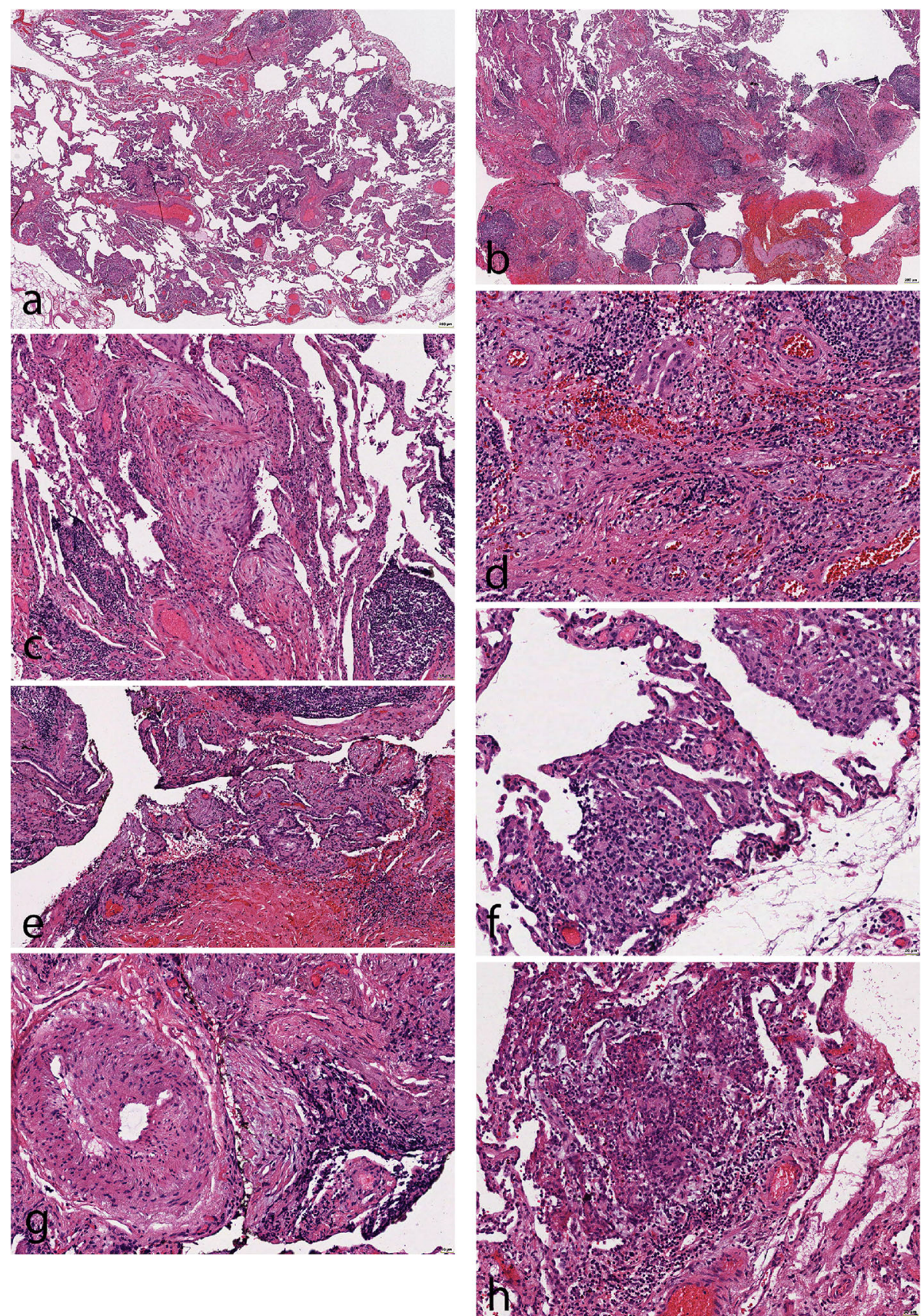

Fig. 24 Chronic hypersensitivity pneumonia, a) inflammatory infiltrates and cystic remodeling is seen, in b) BALT hyperplasia and fibrosis, in c) myofibroblastic foci and lymphocytic infiltrations, in $\mathbf{d}$ ) fibrosis, lymphocytes and multinucleated giant cells; e) shows cystic remodeling and bronchiolar metaplasia, in $\mathbf{f}$ and $\mathbf{h}$ ) ill formed granulomas and giant cells are seen; in $\mathbf{g}$ ) massive sclerosis of a pulmonary artery next to an old myofibroblastic focus are found. H\&E, bars 200, 100, 50, and $20 \mu \mathrm{m}$, respectively

not a sign of confusion or a breakdown in the scientific process, but a sign of vibrancy and a motor for advance" (2003). What does that mean for consensus classification? I think all available data need to be discussed, and controversies upon the diagnosis need to be critically reviewed with these data. After such a critical review, a final diagnosis might be achieved for most cases, but cases with contradictory findings in pathology, radiology, and clinics should kept open for close follow-up of the patient.

\section{Abbreviations}

UIP: usual interstitial pneumonia; NSIP: non-specific interstitial pneumonia; OP: organizing pneumonia; IPF: idiopathic pulmonary fibrosis;

DIP: desquamative interstitial pneumonia; LIP: lymphocytic interstitial pneumonia; GIP: giant cell interstitial pneumonia; ILD: Interstitial Lung 
Disease; RB-ILD: respiratory bronchiolitis - ILD; DAD: diffuse alveolar damage; CD: cluster of differentiation; FOXP3: forkhead box P3; HTERT: human telomerase reverse transcriptase; DKC1: dyskerin pseudouridine synthase 1; TERC: telomerase RNA component; NOP10: NOP10 ribonucleoprotein; NHP2: NHP2 ribonucleoprotein; TINF2: TERF1 interacting nuclear factor 2; ABCA3: ATP binding cassette subfamily A member 3; MUC5B: mucin 5B, oligomeric mucus/gel-forming; HP: hypersensitivity pneumonia; rhA: rheumatoid arthritis; DMM: dermatomyositis; SLE: systemic lupus erythematosus; SSc: systemic sclerosis; IPAF: interstitial pneumonia with autoimmune features; BALT: bronchus associated lymphoid tissue; BOOP: bronchiolitis obliterans - organizing pneumonia

\section{Acknowledgements}

The authors would like to thank the members of the different pulmology and pathology departments for sharing their cases for a second opinion and thus enabling me to gain expertise in this diseases. My special thanks go to the Departments of Pulmology and Pathology at the Hospital MunichBogenhausen for the many years of collaborations.

\section{Author's contributions}

The author planned the review, selected the cases and figures. The author(s) read and approved the final manuscript.

\section{Funding}

There are no funding sources to be declared.

\section{Availability of data and materials}

Not applicable.

\section{Ethics approval and consent to participate}

The use of tissues and patient data has been approved by the Ethics Committee of the Medical University, No. 24-135 ex 11/12; however, patient data were not used in this study.

\section{Consent for publication}

A consent for publication was not necessary as no individual data from patients were used.

\section{Competing interests}

The author declare that he has no competing interests.

Received: 30 December 2019 Accepted: 30 June 2020

Published online: 29 July 2020

\section{References}

Alder JK, Chen JJ, Lancaster L, Danoff S, Su SC, Cogan JD, Vulto I, Xie M, Qi X, Tuder RM, Phillips JA 3rd, Lansdorp PM, Loyd JE, Armanios MY (2008) Short telomeres are a risk factor for idiopathic pulmonary fibrosis. Proc Natl Acad Sci U S A 105:13051-13056

Arakawa H, Yamada H, Kurihara Y, Nakajima Y, Takeda A, Fukushima Y, Fujioka M (2003) Nonspecific interstitial pneumonia associated with polymyositis and dermatomyositis: serial high-resolution CT findings and functional correlation. Chest 123:1096-1103

Araya J, Kojima J, Takasaka N, Ito S, Fujii S, Hara H, Yanagisawa H, Kobayashi K, Tsurushige C, Kawaishi M, Kamiya N, Hirano J, Odaka M, Morikawa T, Nishimura SL, Kawabata Y, Hano H, Nakayama K, Kuwano K (2013) Insufficient autophagy in idiopathic pulmonary fibrosis. Am J Physiol Lung Cell Mol Physiol 304:L56-L69

Bouros D, Wells AU, Nicholson AG, Colby TV, Polychronopoulos V, Pantelidis P, Haslam PL, Vassilakis DA, Black CM, du Bois RM (2002) Histopathologic subsets of fibrosing alveolitis in patients with systemic sclerosis and their relationship to outcome. Am J Respir Crit Care Med 165:1581-1586

Cardenes N, Alvarez D, Sellares J, Peng Y, Corey C, Wecht S, Nouraie SM, Shanker S, Sembrat J, Bueno M, Shiva S, Mora AL, Rojas M (2018) Senescence of bone marrow-derived mesenchymal stem cells from patients with idiopathic pulmonary fibrosis. Stem Cell Res Ther 9:257

Chilosi M, Carloni A, Rossi A, Poletti V (2013) Premature lung aging and cellular senescence in the pathogenesis of idiopathic pulmonary fibrosis and COPD/ emphysema. Transl Res 162:156-173

Costabel U, King TE (2001) International consensus statement on idiopathic pulmonary fibrosis. Eur Respir J 17:163-167
Cottin V, Donsbeck AV, Revel D, Loire R, Cordier JF (1998) Nonspecific interstitial pneumonia. Individualization of a clinicopathologic entity in a series of 12 patients. Am J Respir Crit Care Med 158:1286-1293

Cottin V, Thivolet-Bejui F, Reynaud-Gaubert M, Cadranel J, Delaval P, Ternamian PJ, Cordier JF (2003) Interstitial lung disease in amyopathic dermatomyositis, dermatomyositis and polymyositis. Eur Respir J 22:245-250

Cronkhite JT, Xing C, Raghu G, Chin KM, Torres F, Rosenblatt RL, Garcia CK (2008) Telomere shortening in familial and sporadic pulmonary fibrosis. Am J Respir Crit Care Med 178:729-737

Daniil ZD, Gilchrist FC, Nicholson AG, Hansell DM, Harris J, Colby TV, du Bois RM (1999) A histologic pattern of nonspecific interstitial pneumonia is associated with a better prognosis than usual interstitial pneumonia in patients with cryptogenic fibrosing alveolitis. Am J Respir Crit Care Med 160:899-905

du Bois RM, Wells AU (2001) Cryptogenic fibrosing alveolitis/idiopathic pulmonary fibrosis. Eur Respir J Suppl 32:43s-55s

Enomoto Y, Takemura T, Hagiwara E, Iwasawa T, Okudela K, Yanagawa N, Baba T, Sakai F, Fukuda Y, Nagaoka S, Ogura T (2014) Features of usual interstitial pneumonia in patients with primary Sjogrens syndrome compared with idiopathic pulmonary fibrosis. Respir Investig 52:227-235

Fischer A, Antoniou KM, Brown KK, Cadranel J, Corte TJ, du Bois RM, Lee JS, Leslie KO, Lynch DA, Matteson EL, Mosca M, Noth I, Richeldi L, Strek ME, Swigris JJ, Wells AU, West SG, Collard HR, Cottin V (2015) An official European Respiratory Society/American Thoracic Society research statement: interstitial pneumonia with autoimmune features. Eur Respir J. 46(4):976-87. https://doi. org/10.1183/13993003.00150-2015

Flaherty KR, Andrei AC, King TE Jr, Raghu G, Colby TV, Wells A, Bassily N, Brown K, du Bois R, Flint A, Gay SE, Gross BH, Kazerooni EA, Knapp R, Louvar E, Lynch D, Nicholson AG, Quick J, Thannickal VJ, Travis WD, Vyskocil J, Wadenstorer FA, Wilt J, Toews GB, Murray S, Martinez FJ (2007) Idiopathic interstitial pneumonia: do community and academic physicians agree on diagnosis? Am J Respir Crit Care Med 175:1054-1060

Fujita J, Yoshinouchi T, Ohtsuki Y, Tokuda M, Yang Y, Yamadori I, Bandoh S, Ishida T, Takahara J, Ueda R (2001) Non-specific interstitial pneumonia as pulmonary involvement of systemic sclerosis. Ann Rheum Dis 60:281-283

Garvey W, Fathi A, Bigelow F, Carpenter B, Jimenez C (1986) Improved Movat pentachrome stain. Stain Technol 61:60-62

Kambouchner M, Levy P, Nicholson AG, Schubel K, Magois E, Feuillet S, Valeyre D, Bernaudin JF, Nunes H (2014) Prognostic relevance of histological variants in nonspecific interstitial pneumonia. Histopathology 65:549-560

Katzenstein AL (1993) Idiopathic interstitial pneumonia: classification and diagnosis. Monogr Pathol:1-31

Katzenstein AL, Fiorelli RF (1994) Nonspecific interstitial pneumonia/fibrosis Histologic features and clinical significance. Am J Surg Pathol 18:136-147

Kim DS, Yoo B, Lee JS, Kim EK, Lim CM, Lee SD, Koh Y, Kim WS, Kim WD, Colby TV, Kitiaichi M (2002) The major histopathologic pattern of pulmonary fibrosis in scleroderma is nonspecific interstitial pneumonia. Sarcoidosis Vasc Diffuse Lung Dis 19:121-127

Kropski JA, Mitchell DB, Markin C, Polosukhin W, Choi L, Johnson JE, Lawson WE, Phillips JA, Cogan JD, Blackwell TS, Loyd JE (2014) A novel dyskerin (DKC1) mutation is associated with familial interstitial pneumonia. Chest 146:e1-e7

Kuwano K, Araya J, Hara H, Minagawa S, Takasaka N, Ito S, Kobayashi K, Nakayama K (2016) Cellular senescence and autophagy in the pathogenesis of chronic obstructive pulmonary disease (COPD) and idiopathic pulmonary fibrosis (IPF). Respir Investig 54:397-406

Lawson WE, Cheng DS, Degryse AL, Tanjore H, Polosukhin W, Xu XC, Newcomb DC, Jones BR, Roldan J, Lane KB, Morrisey EE, Beers MF, Yull FE, Blackwell TS (2011) Endoplasmic reticulum stress enhances fibrotic remodeling in the lungs. Proc Natl Acad Sci U S A 108:10562-10567

Lee HK, Kim DS, Yoo B, Seo JB, Rho JY, Colby TV, Kitaichi M (2005) Histopathologic pattern and clinical features of rheumatoid arthritisassociated interstitial lung disease. Chest 127:2019-2027

Liebow A, Carrington C (1969) The interstitial pneumonias. Grune \& Stratton, Orlando

Markart P, Ruppert C, Wygrecka M, Schmidt R, Korfei M, Harbach H, Theruvath I, Pison U, Seeger W, Guenther A, Witt H (2007) Surfactant protein C mutations in sporadic forms of idiopathic interstitial pneumonias. Eur Respir J 29:134137

Myers JL (2007) Nonspecific interstitial pneumonia: pathologic features and clinical implications. Semin Diagn Pathol 24:183-187 
Nathan N, Giraud V, Picard C, Nunes H, Dastot-Le Moal F, Copin B, Galeron L, De Ligniville A, Kuziner N, Reynaud-Gaubert M, Valeyre D, Couderc LJ, Chinet T, Borie R, Crestani B, Simansour M, Nau V, Tissier S, Duquesnoy P, MansourHendili L, Legendre M, Kannengiesser C, Coulomb-L'Hermine A, Gouya L, Amselem S, Clement A (2016) Germline SFTPA1 mutation in familial idiopathic interstitial pneumonia and lung cancer. Hum Mol Genet 25:1457-1467

Nicholson AG, Colby TV, du Bois RM, Hansell DM, Wells AU (2000) The prognostic significance of the histologic pattern of interstitial pneumonia in patients presenting with the clinical entity of cryptogenic fibrosing alveolitis. Am J Respir Crit Care Med 162:2213-2217

Nicholson AG, Colby TV, Wells AU (2002) Histopathological approach to patterns of interstitial pneumonia in patient with connective tissue disorders. Sarcoidosis Vasc Diffuse Lung Dis 19:10-17

Nunes H, Schubel K, Piver D, Magois E, Feuillet S, Uzunhan Y, Carton Z, Tazi A, Levy P, Brillet PY, Nicholson AG, Kambouchner M, Valeyre D (2015) Nonspecific interstitial pneumonia: survival is influenced by the underlying cause. Eur Respir J 45:746-755

Ohtani Y, Saiki S, Kitaichi M, Usui Y, Inase N, Costabel U, Yoshizawa Y (2005) Chronic bird fancier's lung: histopathological and clinical correlation. An application of the 2002 ATS/ERS consensus classification of the idiopathic interstitial pneumonias. Thorax (60):665-671

Ozasa M, Ichikawa H, Sato S, Tanaka T, Johkoh T, Kataoka K, Yamano Y, Kondoh Y, Nakamura H, Kawakami A, Bychkov A, Taniguchi H, Fukuoka J (2018) Proposed method of histological separation between connective tissue disease-associated interstitial pneumonia and idiopathic interstitial pneumonias. PLoS One 13:e0206186

Popper H, StacherPriehse E, Brcic L, Eidenhamme S, Gallob F, Rampp F, Nerlich A (2019) Autophagy and senescence are activated mechanisms in idiopathic or autoimmunity caused usual interstitial pneumonia. ERJ 54:PA5379

Raghu G, Remy-Jardin M, Myers JL, Richeldi L, Ryerson CJ, Lederer DJ, Behr J, Cottin V, Danoff SK, Morell F, Flaherty KR, Wells A, Martinez FJ, Azuma A, Bice TJ, Bouros D, Brown KK, Collard HR, Duggal A, Galvin L, Inoue Y, Jenkins RG, Johkoh T, Kazerooni EA, Kitaichi M, Knight SL, Mansour G, Nicholson AG, SNJ P, Buendia-Roldan I, Selman M, Travis WD, Walsh S, Wilson KC (2018) Diagnosis of Idiopathic Pulmonary Fibrosis. An Official ATS/ERS/JRS/ALAT Clinical Practice Guideline. Am J Respir Crit Care Med 198:e44-e68

Rampp F, Popper H, Meyer J, Modes of disease progression in different forms of interstitial lung disease with usual interstitial pneumonia histology in patients with idiopathic and non-idiopathic etiologies - A single center experience. Eur Respir J. 2019;54. European-Respiratory-Society (ERS) International Congress, Madrid, Spain, Sep 28-Oct 02, 2019. [Poster]

Savage SA, Bertuch AA (2010) The genetics and clinical manifestations of telomere biology disorders. Genetics Med 12:753-764

Seibold MA, Wise AL, Speer MC, Steele MP, Brown KK, Loyd JE, Fingerlin TE, Zhang W, Gudmundsson G, Groshong SD, Evans CM, Garantziotis S, Adler KB, Dickey BF, du Bois RM, Yang IV, Herron A, Kervitsky D, Talbert JL, Markin C, Park J, Crews AL, Slifer SH, Auerbach S, Roy MG, Lin J, Hennessy CE, Schwarz Ml, Schwartz DA (2011) A common MUC5B promoter polymorphism and pulmonary fibrosis. N Engl J Med 364:1503-1512

Selman M, Pardo A (2014) Revealing the pathogenic and aging-related mechanisms of the enigmatic idiopathic pulmonary fibrosis. An integral model. Am J Respir Crit Care Med 189:1161-1172

Selman M, Rojas M, Mora AL, Pardo A (2010) Aging and interstitial lung diseases: unraveling an old forgotten player in the pathogenesis of lung fibrosis. Semin Respir Crit Care Med 31:607-617

Tansey D, Wells AU, Colby TV, Ip S, Nikolakoupolou A, du Bois RM, Hansell DM, Nicholson AG (2004) Variations in histological patterns of interstitial pneumonia between connective tissue disorders and their relationship to prognosis. Histopathology 44:585-596

Travis WD, Costabel U, Hansell DM, King TE Jr, Lynch DA, Nicholson AG, Ryerson CJ, Ryu JH, Selman M, Wells AU, Behr J, Bouros D, Brown KK, Colby TV, Collard HR, Cordeiro CR, Cottin V, Crestani B, Drent M, Dudden RF, Egan J, Flaherty K, Hogaboam C, Inoue Y, Johkoh T, Kim DS, Kitaichi M, Loyd J, Martinez FJ, Myers J, Protzko S, Raghu G, Richeldi L, Sverzellati N, Swigris J, Valeyre D (2013) An official American Thoracic Society/European Respiratory Society statement: Update of the international multidisciplinary classification of the idiopathic interstitial pneumonias. Am J Respir Crit Care Med 188:733-748

Tsakiri KD, Cronkhite JT, Kuan PJ, Xing C, Raghu G, Weissler JC, Rosenblatt RL, Shay JW, Garcia CK (2007) Adult-onset pulmonary fibrosis caused by mutations in telomerase. Proc Natl Acad Sci U S A 104:7552-7557 van Moorsel CH, van Oosterhout MF, Barlo NP, de Jong PA, van der Vis JJ, Ruven HJ, van Es HW, van den Bosch JM, Grutters JC (2010) Surfactant protein C mutations are the basis of a significant portion of adult familial pulmonary fibrosis in a dutch cohort. Am J Respir Crit Care Med 182:1419-1425

Wang Y, Kuan PJ, Xing C, Cronkhite JT, Torres F, Rosenblatt RL, DiMaio JM, Kinch LN, Grishin NV, Garcia CK (2009) Genetic defects in surfactant protein A2 are associated with pulmonary fibrosis and lung cancer. Am J Hum Genet 84:52-59

Waters DW, Blokland KEC, Pathinayake PS, Burgess JK, Mutsaers SE, Prele CM, Schuliga M, Grainge CL, Knight DA (2018) Fibroblast senescence in the pathology of idiopathic pulmonary fibrosis. Am J Physiol Lung Cell Mol Physiol 315:L162-LI72

Yoshinouchi T, Ohtsuki Y, Fujita J, Yamadori I, Bandoh S, Ishida T, Ueda R (2005) Nonspecific interstitial pneumonia pattern as pulmonary involvement of rheumatoid arthritis. Rheumatol Int 26:121-125

Young LR, Nogee LM, Barnett B, Panos RJ, Colby TV, Deutsch GH (2008) Usual interstitial pneumonia in an adolescent with ABCA3 mutations. Chest 134: 192-195

Zhong Q, Zhou B, Ann DK, Minoo P, Liu Y, Banfalvi A, Krishnaveni MS, Dubourd M, Demaio L, Willis BC, Kim KJ, du Bois RM, Crandall ED, Beers MF, Borok Z (2011) Role of endoplasmic reticulum stress in epithelial-mesenchymal transition of alveolar epithelial cells: effects of misfolded surfactant protein. Am J Respir Cell Mol Biol 45:498-509

\section{Publisher's Note}

Springer Nature remains neutral with regard to jurisdictional claims in published maps and institutional affiliations.

\section{Ready to submit your research? Choose BMC and benefit from:}

- fast, convenient online submission

- thorough peer review by experienced researchers in your field

- rapid publication on acceptance

- support for research data, including large and complex data types

- gold Open Access which fosters wider collaboration and increased citations

- maximum visibility for your research: over $100 \mathrm{M}$ website views per year

At BMC, research is always in progress.

Learn more biomedcentral.com/submissions 